\title{
Microalgae Biomolecules: Extraction, Separation and Purification Methods
}

\author{
Priscila S. Corrêa ${ }^{1,2}{ }^{\mathbb{D}}$, Wilson G. Morais Júnior ${ }^{2} \mathbb{D}$, António A. Martins ${ }^{1}$, Nídia S. Caetano ${ }^{1,2, *(D)}$ \\ and Teresa M. Mata ${ }^{1}$ (D)
}

1 LEPABE—Laboratory for Process Engineering, Environment, Biotechnology and Energy, Faculty of Engineering, University of Porto (FEUP), R. Dr. Roberto Frias s/n, 4200-465 Porto, Portugal; eng.pscorrea@gmail.com (P.S.C.); amartins@fe.up.pt (A.A.M.); tmata@fe.up.pt (T.M.M.)

2 CIETI, School of Engineering (ISEP), Polytechnic Institute of Porto (P.Porto), R. Dr. António Bernardino de Almeida 431, 4249-015 Porto, Portugal; wjunioreq@gmail.com

* Correspondence: nsc@isep.ipp.pt or wgdmj@isep.ipp.pt; Tel.: +351-22-834-0500; Fax: +351-22-832-1159

Citation: Corrêa, P.S.; Morais Júnior, W.G.; Martins, A.A.; Caetano, N.S.; Mata, T.M. Microalgae Biomolecules: Extraction, Separation and Purification Methods. Processes 2021, 9, 10. https://dx.doi.org/10.3390/ pr9010010

Received: 1 December 2020

Accepted: 19 December 2020

Published: 22 December 2020

Publisher's Note: MDPI stays neutral with regard to jurisdictional claims in published maps and institutional affiliations.

Copyright: (c) 2020 by the authors. Licensee MDPI, Basel, Switzerland. This article is an open access article distributed under the terms and conditions of the Creative Commons Attribution (CC BY) license (https: / / creativecommons.org/ licenses/by/4.0/).

\begin{abstract}
Several microalgae species have been exploited due to their great biotechnological potential for the production of a range of biomolecules that can be applied in a large variety of industrial sectors. However, the major challenge of biotechnological processes is to make them economically viable, through the production of commercially valuable compounds. Most of these compounds are accumulated inside the cells, requiring efficient technologies for their extraction, recovery and purification. Recent improvements approaching physicochemical treatments (e.g., supercritical fluid extraction, ultrasound-assisted extraction, pulsed electric fields, among others) and processes without solvents are seeking to establish sustainable and scalable technologies to obtain target products from microalgae with high efficiency and purity. This article reviews the currently available approaches reported in literature, highlighting some examples covering recent granted patents for the microalgae's components extraction, recovery and purification, at small and large scales, in accordance with the worldwide trend of transition to bio-based products.
\end{abstract}

Keywords: biomolecules; chromatography; cell disruption; microalgae; purification; supercritical fluids

\section{Introduction}

Microalgae are unicellular or simple multicellular photosynthetic microorganisms, which can normally be found in aquatic environments such as freshwater, seawater, or hypersaline lakes. These organisms can be eukaryotic or prokaryotic, the latter being the cyanobacteria, which are commonly referred to as microalgae. There are numerous microalga species, some of which can grow in high salinity waters, having the advantage of reducing the contamination incidence and expanding its applications [1].

Microalgae can be cultivated photoautotrophically in closed photobioreactors or open ponds, using sunlight, $\mathrm{CO}_{2}$ and inorganic nutrients to grow, producing biomass and $\mathrm{O}_{2}$. However, conventional large-scale photoautotrophic production suffers from low biomass density due to light restrictions that hinder the cells growth, which dramatically increases production cost. Alternatively, microalgae can be grown under mixotrophic or heterotrophic conditions, respectively in the presence and absence of light, adding organic carbon as a nutrient, which has become a common practice for commercial production, increasing the productivity of algal biomass [2].

When compared to higher plants, microalgae have some advantages, such as higher productivity, lack of seasonality and, in the case of biofuel production, do not compete with human food $[3,4]$. Their remarkable biotechnological potential to produce a range of biocomponents such as pigments [5], lipids [6], polysaccharides [7], biopolymers [8], proteins [9], and vitamins [10], among others, has been widely addressed in the literature. 
Most of these bioproducts are stored intracellularly, which requires rupture of the cell wall for their recovery (Figure 1).

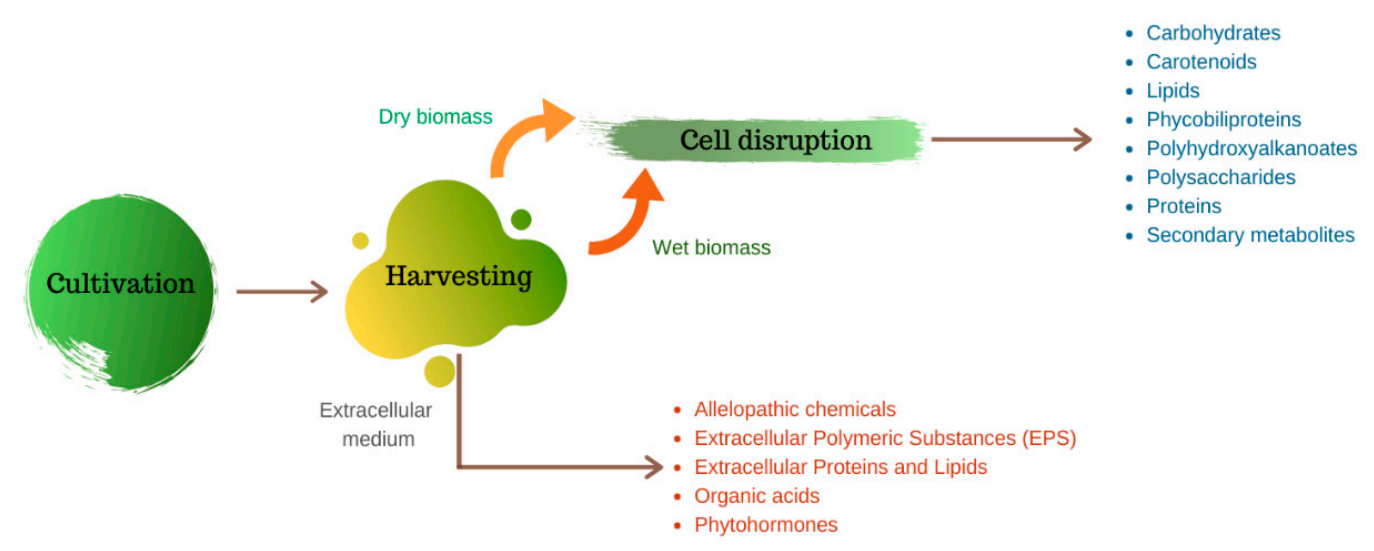

Figure 1. First steps in microalgae production, from cultivation to harvesting and cell disruption, for extraction or recovery of intracellular and extracellular components [11,12].

There are several techniques for cell disruption, which can be applied with greater or lesser degrees of success, depending on the characteristics of the cell wall of a given microalgae species. The rigidity of the cell wall can be provided, for example, by high levels of polysaccharides in the cell wall structure, such as glucose and mannose, present in Chlorella zofingiensis, or by complex sugars composition such as arabinose, galactose, rhaminose, mannose and xylose, as found in Tetraselmis suecia and T. striata. Another extremely resistant component is a non-hydrolyzable biopolymer, called algaenan or sporopollein. This biopolymer is composed of long $\omega$-hydroxy fatty acids chains linked by several types of chemical bond, which confer its rigid properties. Algaenan can be found in some species such as Chlorella spp., Nannochloropsis galditana and Scenedesmus spp. On the other hand, cell walls composed of peptidoglycan, as found in Arthorspira spp., are less rigid and, consequently, more susceptible to degradation $[13,14]$.

In this sense, several authors have studied the effect of different cell disruption techniques in order to enhance the recovery of the intracellular target product. Larrosa et al. [15] tested three different cellular rupturing techniques (i.e., milling, microwave oven and autoclaving) to enhance the recovery of phycocyanin and phenolic compounds from Spirulina sp. (strain LEB-18). In addition, Gim and Kim [16] tested several experimental conditions to optimize six cell disruption methods applied to Botryococcus braunii LB572 biomass, including mechanical (sonication, bead-beater, autoclave, French-press and microwave) and non-mechanical (osmotic shock) methods. More recently, Martínez et al. [17] proposed the use of pulsed electric fields (PEF) for astaxanthin extraction from Haematococcus pluvialis, comparing the extraction efficiency of PEF with classical methods, such as bead-beating, ultrasound, freezing-thawing, thermal and chemical treatments.

Biomolecule recovery and purification may be limiting factors for the establishment of biotechnological processes, by making them economically less attractive than chemical ones [18]. However, the development of new, more efficient and sustainable technologies and processes can be the key to promote the transition to bio-based products [19]. In the following sections, the main technologies for cell disruption, selective extraction, recovery and purification of microalgae biomolecules are discussed. Hence, this paper reviews the most common methods for extracting and purifying different components from microalgal biomass. It presents examples of various microalgae species and the methods used to extract the desired components with each one.

\section{Cell Disruption Methods}

Methods for microalgae cell disruption comprise mechanical, physical or non-mechanical techniques, usually employed to disrupt or disintegrate the cellular membrane, this way 
increasing the recovery yield of the desired component (e.g., lipids, pigments, proteins) that can be isolated from biomass. Figure 2 shows the general differences between mechanical and non-mechanical cell-disruption methods.

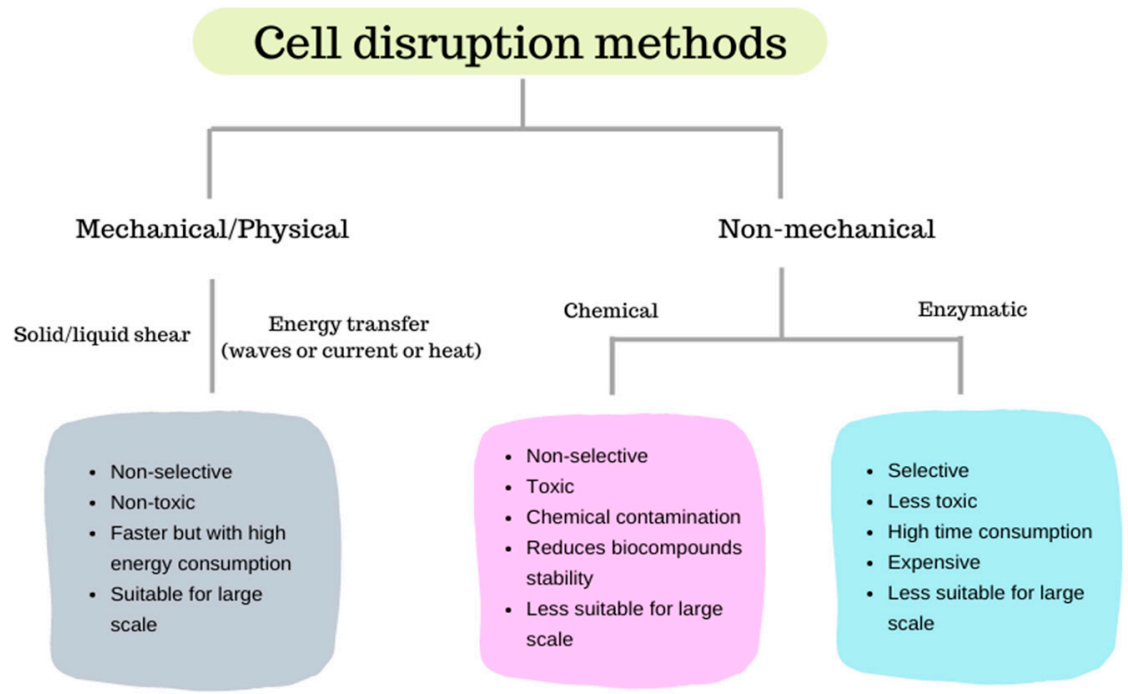

Figure 2. Comparison of different cell-disruption methods.

\subsection{Mechanical and Physical Methods}

Mechanical and physical methods may promote cell lysis through solid or liquidshear forces (e.g., bead milling, high-speed or high-pressure homogenization) or energy transfer through waves (e.g., microwave irradiation, ultrasonication or laser), current (e.g., pulsed electric fields) or heat (e.g., autoclaving, freeze/thaw cycles, thermolysis).

\subsubsection{Bead Milling}

The cell disruption principle in bead mill machines is to promote mechanical cell damage by forcing the collision between the cells and the beads. This collision is promoted by a rotating shaft present in the grinding chamber. The diameter and load of the beads are important parameters with a direct influence on the cell disruption effectiveness [20]. The most common materials used in the beads are zirconium (high-density beads) and glass (low-density beads). Zirconium is preferred to process high viscosity media, while glass beads are more suitable for media with low viscosity [21].

In large-scale processes, techniques based on solid/liquid-shear forces are commonly employed due to their high efficiency and scale-up easiness. Furthermore, these methods avoid the contamination of chemical methods and preserve most of the biomolecules' functionality when compared to chemical and thermal treatments. An optimized mechanical method for Chlorella's cell wall disruption at industrial scale (i.e., milling chamber volume $\geq 500 \mathrm{dm}^{3}$ and/or flow rate $>1 \mathrm{~m}^{3} \cdot \mathrm{h}^{-1}$ and/or batch from 1 to $200 \mathrm{~m}^{3}$ ) has been described in the US patent $\mathrm{n}^{\circ} 10465159 \mathrm{~B} 2$ [22]. The inventors evaluated the effect of specific parameters, such as bead material (glass, zirconium silicate and zirconium oxide), diameter of milling beads ( 0.3 to $1.7 \mathrm{~mm}$ ), chamber filling rate $(80 \%$ to $90 \%)$, operational scheme (single or multiple mills in series), peripheral speed of milling disks (8 to $12 \mathrm{~m} \cdot \mathrm{s}^{-1}$, limited to avoid abrasion issues) and cell density (20\%, 25.2\% and $31.9 \%$ ) on the specific energy demand and productivity. The configuration recommended by the applicant company in order to combine lower energy consumption with higher productivity is performed by lower diameter-zirconium silicate beads $(0.3$ to $0.6 \mathrm{~mm})$ at $85-90 \%$ chamber filling rate, peripheral speed of milling disks between 11 and $12 \mathrm{~m} \cdot \mathrm{s}^{-1}$ and moderate biomass concentration $(25.2 \%)$ with several mills in series. It was demonstrated that moderate conditions are preferable to reduce energy consumption to achieve a target degree of milling. Despite high-density beads (based on zirconium) presenting high specific energy, the glass 
beads (low density) were not efficient, requiring more passes to achieve the same degree of milling, which also increases the specific energy. Therefore, in order to overcome this issue, the inventors combined the use of zirconium silicate, which is less dense than zirconium oxide, with lower diameter to reduce the number of passes required. The same criteria were applied to biomass concentration; higher concentrations lead to higher productivities, but also increase the energy consumption. Additionally, moderate peripheral speed was recommended to avoid excessive abrasion and the filling rate, however, did not present a significant impact on energy consumption among the tested conditions. It is also possible to reduce the specific energy consumption and the process cost by using higher dry cell weight concentrations $(0.5-8 \% w / w)$ and higher biomass flow rates, but it will also have a negative impact on the cell disruption efficiency [21]. Thus, despite the many advantages of using bead milling, including this being a suitable technique for large-scale production, and the aforementioned optimizations, this process still has high energy consumption [23]

\subsubsection{High-Speed Homogenization}

High-speed homogenization (HSH) is a simple and effective method, in which the cells' disruption is based on hydrodynamic cavitation caused by stirring at high speed $(10,000-20,000 \mathrm{rpm})$ and shear forces at the solid-liquid interphase [21]. Despite presenting some drawbacks such as high energy consumption and protein denaturation, this technique is suitable for industrial scale and requires short processing time. It has been reported operational times of 30 or $60 \mathrm{~s}$ at 10,000 or 14,000 rpm for lipid and antioxidant extraction in Nannochloropsis sp., Phaeodactylum tricornutum and Pavlova lutheri [24,25].

González-Delgado and Kafarov [26] compared solvent assisted extraction with HSH and other solvent-based extraction methods for a microalgae biorefinery. The authors tested five microalgae species (Nannochloropsis sp., Guinardia sp., Closterium sp., Amphiprora sp. and Navicula sp.), concluding that despite the higher extraction yields achieved by combining polar and non-polar solvents, the solvent method presents high toxicity and lowest solvent recovery, increasing the process costs.

\subsubsection{High-Pressure Homogenization}

The high-pressure homogenization (HPH) method for cell disruption employs high pressure $(\approx 20-120 \mathrm{MPa})$ to promote turbulence, liquid-shear stress and friction. According to the cell wall properties, parameters such as operating pressure and number of homogenization passes can be optimized to enhance the process efficiency [27]. Additionally, other variables such as dry cell weight concentration, microalgae species and growth conditions, impacts on the specific energy consumption [21].

Bernaerts et al. [28] studied the impact of (ultra) high-pressure homogenization (U)HPH on the rigid cells of Nannochloropsis sp., achieving similar lipid extraction efficiency, using $250 \mathrm{MPa}$ in half of the homogenization passes compared to $100 \mathrm{MPa}$. However, despite the effective reduction of homogenization passes, the high pressure also heated the sample, resulting in aggregation of the intracellular components released. Besides the reduction of specific energy in (U)HPH by using biomass concentrations up to $25 \%$ $(w / w)$, the energy consumption of this technique is still high. However, Elain et al. [29] demonstrated a satisfactory specific energy consumption $\left(0.41 \mathrm{kWh} \cdot \mathrm{kg}^{-1}\right.$ biomass dry weight) of HPH in a study comparing the performance of this technique in mild conditions (e.g., of room temperature, neutral $\mathrm{pH}$, shorter time, etc.) with conventional thermal treatment (hot water) in cell disruption of Arthrospira platensis, also increasing 2.5-fold the yield of polysaccharides extraction.

Thus, the major drawbacks of HPH comprise the non-selectivity, the formation of undesirable cell debris and the limitation to break harder cell walls. However, despite these disadvantages, $\mathrm{HPH}$ is, together with bead milling and $\mathrm{HSH}$, the preferred method for the industrial scale. 


\subsubsection{Microwave Irradiation}

Microwave irradiation is a simple and scalable method for cell disruption. This method has a well-established optimal operational value for heating $(2450 \mathrm{MHz})$ and the cell walls are disrupted by the electromagnetic effect induced by the microwave irradiance that interacts with polar (e.g., water) and dielectric molecules, also promoting local heating [30]. This method is not suitable when the target component is volatile, but it has been successfully reported as an effective cell disruption technique for lipid extraction. Also, the combination of microwave with solvents, called microwave-assisted extraction (MAE), has been reported as the technique with lower operational costs and extraction time than the conventional techniques, and higher lipid extraction than other non-conventional methods (e.g., ultrasound-assisted extraction) [31].

By comparing different cell disruption methods (autoclaving, bead-beating, microwaves, sonication and osmotic shock), followed by chemical lipid extraction, Lee et al. [32] proved that microwave was the most effective method for cell disruption of three microalgae species (Botryococcus sp., Chlorella vulgaris and Scenedesmus sp.). In addition, by using a microwave method, Dai et al. [33] achieved the highest lipids extraction yield (18 wt\%) from commercial microalgae dry powder, in comparison with $14 \mathrm{wt} \%$ by heating and $5 \mathrm{wt} \%$ by ultrasound. Also, Viner et al. [34] compared microwave with several cell disruption methods (freeze-drying, ultrasonication, cooling, liquid nitrogen grinding, osmotic shock and switchable osmotic shock) prior to lipid extraction in Scenedesmus sp. using liquid $\mathrm{CO}_{2}$ and methanol. The highest total lipids extraction yield (9.6 wt\% of dry algae) was achieved using microwave in the presence of water. Recently, the use of ionic liquids in MAE has been studied as a greener technology to overcome the intrinsic toxicity of the conventional solvents (e.g., chloroform, methanol) [35,36].

\subsubsection{Ultrasonication}

The ultrasonication method for cell disruption is based on liquid-shear forces caused by emission of high frequency wave sounds (up to $15-20 \mathrm{kHz}$ ). In liquid, these sound waves create gas bubbles or cavities that, after a certain number of cycles, achieve a critical size, collapsing and releasing large amounts of energy. Additionally, acoustic cavitation occurs by increasing local temperature and forming hydroxyl radicals that damage the cell wall [20]. Besides being a scalable technique with low operational cost, it is possible to optimize some parameters (e.g., temperature, cell concentration, acoustic intensity and time) to partially disrupt the cells, resulting in selective release of proteins [27]. Moreover, the promising use of ultrasonication for large-scale treatment of microalgal biomass has been previously pointed out by Adam et al. [37] who suggested that, the large-scale ultrasound extraction reactors used in food and chemical industries, can be easily modified to perform an ultrasound-assisted extraction of microalgae biomolecules in amounts up to $200 \mathrm{~kg} \cdot \mathrm{h}^{-1}$ of biomass dry weight. However, this technique is not very effective for some microalgae species and it is commonly combined with chemical treatments for efficiency improvement and to reduce energy demand $[23,27]$.

\subsubsection{Pulsed Electric Field}

A pulsed electric field (PEF) has been described as an alternative method to overcome high energy consumption of classical mechanical methods based on solid/liquid-shear forces. Besides being energetically efficient and scalable, PEF also presents selectivity and fast processing time. However, despite the low operational costs, equipment is expensive and the technique depends on medium conductivity, limiting its use [38]. The disruption mechanism induced by PEF is based on electroporation as a result of transient membrane-permeabilization and electrophoretic movements into the cell caused by charged species [39]. The electroporation can be reversible $\left(0.5-1.5 \mathrm{kV} \cdot \mathrm{cm}^{-1}, 0.5-5 \mathrm{~kJ} \cdot \mathrm{kg}^{-1}\right)$, mostly used for genetic engineering or chemotherapy, or irreversible $\left(10-20 \mathrm{kV} \cdot \mathrm{cm}^{-1}, 50-200 \mathrm{~kJ} \cdot \mathrm{kg}^{-1}\right)$, being applicable for cell disruption and food processing [40]. 
Several parameters can influence PEF efficiency such as the electric field strength, pulse (shape, width), frequency, physicochemical parameters (temperature, $\mathrm{pH}$ and conductivity), operational time and cell wall properties [41]. Lam et al. [42] tested the use of PEF for protein release from Chlorella vulgaris and Neochloris oleoabundans achieving the maximum of $13 \%$ even through use of 10-100 times higher energy than bead milling, which released $45-50 \%$ of proteins. On the other hand, Käferböck et al. [43] reported a $90 \%$ increase in phycocyanin extraction efficiency from Arthrospira maxima by combining freeze-thawing and PEF, in comparison to bead milling method. However, a recent study comparing PEF, high voltage electrical discharges (HVED) and ultrasonication on aqueous extraction of Nannochloropsis sp., Phaeodactylum tricornutum and Parachlorella kessleri components have demonstrated HVED is most effective for carbohydrates and ultrasonication for proteins and chlorophyll a extraction from these species [44]. These results demonstrate that despite being a promising technology, there are still challenges to overcome for its establishment as a suitable technology for mild or large-scale microalgae biorefinery. However, PEF is a widely employed technology in the food industry that counts on specialized companies that are also involved in projects, approaching the use of PEF to stimulate growth and improve extraction of high-value compounds from microalgae. The German company ELEA Technology, for example, has been running the project iAlgaePro (https:/ /elea-technology.de/project/ ialgaepro/) since 2014. In this project the effectiveness of low-intensity PEF treatments to stimulate growth and also enhance the extraction of several compounds (e.g., phycocyanin, vitamins, polyphenols, lipids, among others) were demonstrated. The group reported significant difference between the phycocyanin extraction yield in PEF-treated (66.4 mg $\left.\mathrm{mL}^{-1}\right)$ and non-treated $\left(\leq 0.2 \mathrm{mg} \cdot \mathrm{mL}^{-1}\right)$ Spirulina biomass. Thus, this kind of initiative may accelerate the implementation of PEF in microalgae biorefineries.

\subsubsection{Thermal Treatments}

Thermal treatments are physical methods that use heat to promote cell disruption, such as thermolysis [45], autoclaving [15] and steam explosion [46,47]. Despite being simple technologies with low maintenance cost, the physical disruption is frequently associated with low efficiency, high energy consumption, generation of large amounts of undesirable cell debris and applicability limited by thermal resistance of the target product to be extracted. However, as shown in Table 1, steam explosion has many advantages compared to conventional thermal treatments. In this technique the biomass is exposed to high temperatures $\left(160-290{ }^{\circ} \mathrm{C}\right)$, however, to pretreated microalgae biomass it is recommended to use lower temperatures to avoid degradation of the bioproducts, at vapor pressure between 1.03 and $3.45 \mathrm{MPa}$. The cell disruption occurs when the system is depressurized to return to room conditions [48,49]. Lorente et al. [46] tested four pretreatments (steam explosion, autoclaving, microwave and ultrasound) in three microalgae species (Nannochloropsis gaditana, Phaeodactylum tricornutum and Chlorella sorokiniana) to enhance lipid extraction using the Bligh and Dyer method. In this study, steam explosion as pretreatment showed the highest lipid yield for all species, especially for N. gaditana and C. sorokiniana. Furthermore, this technique promotes carbohydrates hydrolysis, forming aqueous phase rich in monomeric sugars suitable for subsequent fermentation. 
Table 1. Main mechanical and physical methods for cell disruption: mechanism of disruption, advantages, disadvantages and remarks.

\begin{tabular}{|c|c|c|c|c|c|c|}
\hline $\begin{array}{l}\text { Cell Disruption } \\
\text { Method }\end{array}$ & $\begin{array}{l}\text { Principle of Cell } \\
\text { Disruption }\end{array}$ & Advantages & Disadvantages & Remarks & Equipment Available & Specifications \\
\hline $\begin{array}{c}\text { Bead milling } \\
{[21,49,50]}\end{array}$ & $\begin{array}{c}\text { Mechanical } \\
\text { deformation by } \\
\text { compaction and shear }\end{array}$ & 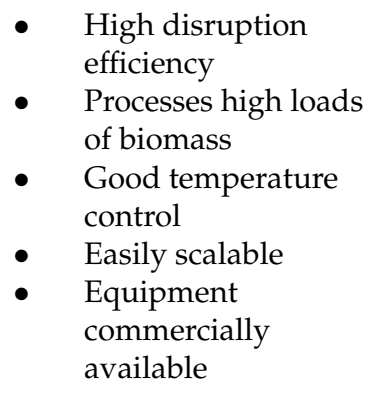 & 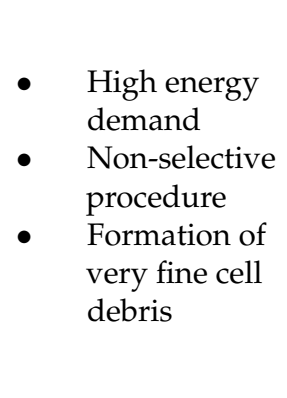 & $\begin{array}{l}\text { Suitable for } \\
\text { large-scale }\end{array}$ & $\begin{array}{l}\text { Bead mill for cell } \\
\text { disruption-model EDW } \\
\left(\text { ELE }^{\circledR} \text { Company }\right)^{\mathrm{a}}\end{array}$ & $\begin{array}{l}\text { Chamber volume: } \\
\text { 5-400 L } \\
\text { Power: } 11-500 \mathrm{~kW} \\
\text { Speed: } 0-480 \text { to } \\
0-1500 \mathrm{rpm} ; \\
\text { Dimension: various. } \\
\text { Flow: } 30-200 \text { to } \\
\text { >3000 L } \mathrm{h}^{-1} \text { Weight: } \\
400-11,700 \mathrm{~kg}\end{array}$ \\
\hline $\begin{array}{c}\text { High-speed } \\
\text { homogenization } \\
{[21]}\end{array}$ & Cavitation and shear & $\begin{array}{ll}\text { - } & \text { Simple } \\
\text { - } & \text { High disruption } \\
\text { - } & \text { efficiency } \\
& \text { Short contact times }\end{array}$ & $\begin{array}{ll}\text { - } & \text { High energy } \\
\text { demand } \\
\text { - } \quad \text { Protein } \\
\text { denaturation }\end{array}$ & $\begin{array}{l}\text { Preferable for large } \\
\text { scale (not indicated } \\
\text { for mild scale) }\end{array}$ & $\begin{array}{l}\text { High-speed homogenizer } \\
\text { and disperser } \\
\left(\text { Intertech }{ }^{\circledR}\right)^{b}\end{array}$ & $\begin{array}{l}\text { Volume: } 750-1150 \mathrm{~L} \\
\text { Power: } 5-75 \mathrm{hp} \\
\text { Speed: } \\
\text { 1000-2880 rpm } \\
\text { Flow rate: } \\
\text { 650-5200 L min }{ }^{-1} \\
\text { Dimension: various }\end{array}$ \\
\hline
\end{tabular}


Table 1. Cont.

\begin{tabular}{|c|c|c|c|c|c|c|}
\hline $\begin{array}{l}\text { Cell Disruption } \\
\text { Method }\end{array}$ & $\begin{array}{l}\text { Principle of Cell } \\
\text { Disruption }\end{array}$ & Advantages & Disadvantages & Remarks & Equipment Available & Specifications \\
\hline $\begin{array}{c}\text { High-pressure } \\
\text { homogenization } \\
{[17,20,50]}\end{array}$ & Cavitation and shear & $\begin{array}{ll}\text { - } & \text { Easily scalable } \\
\text { - } & \text { Does not require cell } \\
\text { drying } \\
\text { - } & \text { Suitable for } \\
& \text { processing large } \\
& \text { volumes }\end{array}$ & $\begin{array}{l}\text { Non-selective } \\
\text { procedure } \\
\text { Use low dry cell } \\
\text { weight } \\
\text { concentrations, } \\
\text { increasing } \\
\text { energy demand } \\
\text { and water } \\
\text { footprint } \\
\text { Formation of } \\
\text { very fine cell } \\
\text { debris } \\
\text { Not effective to } \\
\text { break hard cell } \\
\text { walls } \\
\text { Reduces protein } \\
\text { disgestibility } \\
\text { No indicate for } \\
\text { fragile } \\
\text { compounds } \\
\text { isolation }\end{array}$ & $\begin{array}{ll}\text { - } & \text { Suitable for } \\
\text { emulsification } \\
\text { processes }\end{array}$ & $\begin{array}{c}\text { Ariete Series } \\
\text { Homogenizers(@GEA } \\
\text { Group) }{ }^{c} \\
\text { DeBEE } 2000 \text { series } \\
\text { (CBEE International) }{ }^{d}\end{array}$ & $\begin{array}{c}\text { Pressure: } \\
\text { 100-1500 bar } \\
\text { Flow: } \\
\text { 35-80,000 L h }{ }^{-1} \\
\text { Power: } 10 \mathrm{hp} \\
\text { Pressure: } \\
\text { 1333-45,000 bar } \\
\text { Flow rate: } \\
\text { 0.5-2 L min } \\
\text {-1 }\end{array}$ \\
\hline $\begin{array}{c}\text { Microwave } \\
\text { irradiation } \\
{[17,21,50]}\end{array}$ & $\begin{array}{l}\text { Increases temperature } \\
\text { and molecular energy }\end{array}$ & $\begin{array}{ll}\text { - } & \text { Easily scalable } \\
\text { - } & \text { Simple } \\
\text { - } & \text { Can be combined } \\
& \text { with selective } \\
& \text { extraction } \\
& \text { (microwave assisted } \\
\text { extraction) }\end{array}$ & $\begin{array}{l}\text { - } \\
\text { volatile } \\
\text { compounds } \\
\text { isolation } \\
\text { - } \quad \text { Limited to polar } \\
\text { solvents }\end{array}$ & $\begin{array}{l}\text { Not recommended for } \\
\text { mild microalgae } \\
\text { biorefinery }\end{array}$ & $\begin{array}{l}\text { MARS }^{\mathrm{TM}_{6}} \text { Extraction } \\
\text { (CCEM Corporation) }^{\mathrm{e}}\end{array}$ & $\begin{array}{l}\text { Capacity: } 55 \mathrm{~L} \text {, up } \\
\text { to } 40 \text { vessels } \\
\text { Wattage: } 2000 \mathrm{~W} \\
\text { Power density: } \\
36 \mathrm{~W} \mathrm{~L}^{-1}\end{array}$ \\
\hline
\end{tabular}


Table 1. Cont.

\begin{tabular}{|c|c|c|c|c|c|c|}
\hline $\begin{array}{l}\text { Cell Disruption } \\
\text { Method }\end{array}$ & $\begin{array}{l}\text { Principle of Cell } \\
\text { Disruption }\end{array}$ & Advantages & Disadvantages & Remarks & Equipment Available & Specifications \\
\hline $\begin{array}{c}\text { Ultrasonication } \\
{[17,20,27]}\end{array}$ & $\begin{array}{l}\text { Cavitation and free } \\
\text { radical formation }\end{array}$ & $\begin{array}{ll}\text { - } & \text { Easily scalable } \\
\text { - } & \text { Low operational } \\
& \text { costs }\end{array}$ & $\begin{array}{l}\text { - Low cell } \\
\text { disruption } \\
\text { efficiency for } \\
\text { some microalgae } \\
\text { species } \\
\text { - } \quad \text { Heat production }\end{array}$ & $\begin{array}{l}\text { - Combination of } \\
\text { ultrasound with } \\
\text { different } \\
\text { solvents can } \\
\text { improve the } \\
\text { effectiveness of } \\
\text { cell disruption } \\
\text { and reduce the } \\
\text { energy demand } \\
\text { Equipment } \\
\text { already } \\
\text { available for } \\
\text { industrial scale }\end{array}$ & $\begin{array}{c}\text { Industrial ultrasonic } \\
\text { devices UIP series } \\
\text { (Hielscher Ultrasonics) }^{\mathrm{f}}\end{array}$ & $\begin{array}{c}\text { Power: } 0.5-16 \mathrm{~kW} \\
\text { Frequency: } 18 \text { or } \\
20 \mathrm{kHz} \\
\text { Flow rate: } \\
0.25-10 \mathrm{~m}^{3} \mathrm{~h}^{-1}\end{array}$ \\
\hline $\begin{array}{l}\text { Pulsed electric } \\
\text { fields }[17,21]\end{array}$ & $\begin{array}{l}\text { Irreversible pore } \\
\text { formation in cell } \\
\text { membrane caused by } \\
\text { short electrical pulses } \\
\text { (electroporation) }\end{array}$ & $\begin{array}{ll}\text { - } & \text { High disruption } \\
\text { efficiency } \\
\text { - } & \text { Low operational } \\
& \text { costs } \\
\text { - } & \text { Scalable } \\
\text { - } & \text { Selective } \\
\text { - } & \text { Fast process time }\end{array}$ & $\begin{array}{l}\text { Can promote } \\
\text { radical } \\
\text { formation and } \\
\text { undesired } \\
\text { reactions, } \\
\text { reducing the } \\
\text { quality of the } \\
\text { product } \\
\text { Depends on the } \\
\text { media } \\
\text { conductivity } \\
\text { Expensive } \\
\text { equipment }\end{array}$ & $\begin{array}{c}\text { Needs improvements } \\
\text { for cell disruption in } \\
\text { large-scale }\end{array}$ & $\begin{array}{l}\text { ELEA PEFPilot }^{\mathrm{TM}} \text { dual } \\
\text { trial system } \\
\text { (ELEA Technology) }^{\mathrm{g}}\end{array}$ & $\begin{array}{l}\text { Power: } 400 \mathrm{~V}, 50 \mathrm{~Hz} \text {; } \\
\text { Water and air } \\
\text { cooled } \\
\text { Dimensions: } \\
1,45 \times 1,79 \times 1,13 \\
(\mathrm{~W} \times \mathrm{D} \times \mathrm{H}) \\
\text { Capacity: } 10 \mathrm{~kg} \text { per } \\
\text { batch, up to } \\
250 \mathrm{~L} \mathrm{~h}^{-1}\end{array}$ \\
\hline
\end{tabular}


Table 1. Cont.

\begin{tabular}{|c|c|c|c|c|c|c|}
\hline $\begin{array}{l}\text { Cell Disruption } \\
\text { Method }\end{array}$ & $\begin{array}{l}\text { Principle of Cell } \\
\text { Disruption }\end{array}$ & Advantages & Disadvantages & Remarks & Equipment Available & Specifications \\
\hline $\begin{array}{c}\text { Autoclaving } \\
{[49,50]}\end{array}$ & $\begin{array}{l}\text { Exterior heat } \\
\text { diffusion through cell } \\
\text { membrane to } \\
\text { intracellular } \\
\text { environment }\end{array}$ & $\begin{array}{ll}\text { - } & \text { Simple } \\
\text { - } & \text { Low maintenance } \\
\text { costs }\end{array}$ & $\begin{array}{l}\text { - High energy } \\
\text { consumption } \\
\text { - } \quad \text { Formation of } \\
\text { large amount of } \\
\text { cell debris } \\
\text { - Not indicated } \\
\text { for } \\
\text { thermal-sensible } \\
\text { compounds }\end{array}$ & $\begin{array}{l}\text { Not indicated for } \\
\text { large-scale }\end{array}$ & $\begin{array}{l}\text { Systec V series } \\
(\text { Systec } \mathrm{GmbH})^{\mathrm{h}}\end{array}$ & $\begin{array}{c}\text { Chamber volume: } \\
45 / 40- \\
166 / 150 \mathrm{~L}_{\text {total/nominal }}\end{array}$ \\
\hline $\begin{array}{c}\text { Steam explosion } \\
{[49,50]}\end{array}$ & $\begin{array}{l}\text { High temperature, } \\
\text { vapor pressure and } \\
\text { depressurization }\end{array}$ & $\begin{array}{ll}\text { - } & \text { Low maintenance } \\
\text { costs } \\
\text { - } & \text { Relatively low } \\
\text { energy consumption } \\
\text { - } & \text { Low corrosion } \\
\text { potential } \\
\text { - } \\
\text { Residual steam can } \\
\text { be used to reduce } \\
\text { process costs }\end{array}$ & $\begin{array}{l}\text { Variable } \\
\text { efficiency } \\
\text { according to } \\
\text { microalgae } \\
\text { species }\end{array}$ & $\begin{array}{l}\text { Very suitable for } \\
\text { commercial } \\
\text { applications }\end{array}$ & $\begin{array}{c}\text { Steam generator various } \\
\text { models } \\
\left(_{(\text {Garioni Naval })^{\mathrm{i}}}\right.\end{array}$ & $\begin{array}{c}\text { Lab-scale: } 15- \\
180 \mathrm{~kW}, \\
9-170 \mathrm{~kg}_{\text {steam }} \mathrm{h}^{-1} \\
7-8 \text { barg } \\
\text { Up scales: } 300- \\
6000 \mathrm{~kg}_{\text {steam }} \mathrm{h}^{-1} \\
3 \text { passes, up to } \\
18 \text { barg; } 3000- \\
25,000 \mathrm{~kg}_{\text {steam }} \mathrm{h}^{-1} \\
2 \text { passes, up to } \\
21 \text { barg }\end{array}$ \\
\hline
\end{tabular}

Websites: ${ }^{a}$ www.ele-mix.c

www.systec-lab.com, ${ }^{i}$ www.garioninaval.com. $(\mathrm{W} \times \mathrm{D} \times \mathrm{H})$ : Width $\times$ Depth $\times$ Height. 
In Table 1 are summarized the main mechanical and physical methods for cell disruption, highlighting the principle of cell disruption and the main advantages and disadvantages of each of them.

\subsection{Non-Mechanical Methods}

Non-mechanical methods comprise chemical methods that may use acid or alkaline treatments [51-53] and detergents [54], osmotic shock [16] or enzymatic treatments [55,56].

\subsubsection{Chemical Methods}

Chemicals such as solvents, acids, alkali, hypochlorites, antibiotics, detergents, among others, can interact with components of the microalgal cell wall causing deformations and promoting cell disruption. Despite being a simple and well-known technique, the use of chemicals raises several environmental and economic concerns, especially for industrial scale. Further, the chemical contamination of the target product limits its application, once the active compound is generally classified as non-food grade [20]. However, the use of surfactants, which can both help harvesting biomass and promote cell disruption, is an interesting option in large scale for species whose harvest is a limiting factor. Surfactants interact with the cell membrane's phospholipids, causing distortions and consequently, cell disruption, improving release of intracellular components and bioproducts recovery [54]. The most commonly used surfactants are long-chain alkyl groups (C12 to C16) containing quaternary-ammonium cation. These compounds have hydrophobic ends capable of adsorbing or attaching to cell membranes, and once this happens, the quaternary cation makes the cell charge to become less negative, favoring cell aggregation [57]. Lai et al. [58] evaluated this synergistic effect by using cationic surfactants for flocculation and lipid extraction from C. vulgaris. The authors tested three cationic surfactants: dodecyltrimethylammonium bromide (DTAB), myristyltrimethylammonium bromide (MTAB) and hexadecyltrimethylammonium bromide (CTAB), showing that the pretreatment with the surfactant CTAB resulted in the most effective cell disruption, with the highest lipid recovery (nearly $90 \%$ ) without changing the fatty acid methyl esters (FAME) profile. Moreover, small amounts of CTAB $(0.45 \mathrm{mM})$ were required to improve flocculation and harvesting. Recently, Alhattab et al. [59] tripled the amount of total FAME extracted by 24 hours' pretreatment with the surfactant $\mathrm{CTAB}$, followed by SFE with supercritical $\mathrm{CO}_{2}\left(\mathrm{sc}-\mathrm{CO}_{2}\right)$ of Chlorella saccharophila biomass. However, they also observed that although the extraction was higher, the FAME composition changed significantly. This possibility of modulating FAME composition may be interesting depending on the desired application, but for biodiesel production, they found that the most suitable composition was obtained with pure sc- $\mathrm{CO}_{2}$. Additionally, in the US patent $n^{\circ}$ 9994791B1, Zhang et al. [56] described a cell disruption method for microalgae Nannochloropis salina by using sodium dodecylbenzenesulfonate as anionic surfactant associated to $\mathrm{pH}$ adjustment and low pressurization, extending this application to other anionic and non-ionic surfactants.

\subsubsection{Osmotic Shock}

The presence of a high concentration of solute (salt, dextran or polyethylene glycol (PEG)) leads to a decrease of osmotic pressure, causing cell wall damage, increasing its permeability and, consequently, allowing the release of intracellular compounds. In this respect, Rakesh et al. [60] compared the use of autoclaving, microwave, osmotic shock, and pasteurization to Chlorococcum sp. MCC30, Botryococcus sp. MCC31, Botryococcus sp. MCC32, and Chlorella sorokiniana MIC-G5 to facilitate lipid extraction. They found that by applying osmotic shock improved lipid extraction could be achieved for Botryococcus sp. MCC32 (at 15\% NaCl) and for C. sorokiniana MIC-G5 (at 5\% NaCl). Furthermore, the composition of the extracts varied with the treatment used to facilitate the extraction. Rakesh et al. [60] also found different palmitate (C16:0) contents $(25.64 \%$ and $34.20 \%)$ using osmotic shock ( $15 \% \mathrm{NaCl})$ treatment for Botryococcus sp. MCC 32 and microwave (6 min) for Botryococcus sp. MCC31, respectively, while the use of Botryococcus sp. MCC32 
as source of oil blends or nutraceuticals was proposed after osmotic shock of $15 \% \mathrm{NaCl}$ treatment due to its oleic acid and unsaturated fatty acid content $(19.95 \%$ and $38.17 \%$, respectively). González-González et al. [61] also applied osmotic shock to Chaetoceros muelleri and Dunaliella salina, having achieved a lipid recovery efficiency of $72 \%$ and $21 \%$ respectively. They also found that the lipid-spent biomass of $C$. muelleri add one of the highest methane yields reported for microalgae of $484 \mathrm{~mL} \mathrm{CH}_{4} \mathrm{~g} \mathrm{VS}^{-1}$, showing that osmotic shock adds a double positive effect on lipid extraction and biomass quality for anaerobic digestion. López and Morales [62] extracted astaxanthin from Haematococcus pluvialis applying osmotic shock by highly concentrated sacarose solution, or syrup, at high temperatures. They concluded that astaxanthin extracted using osmotic shock remained available for consumption in the syrup. Koyande et al. [63] studied the recovery of whole proteins from Chlorella vulgaris FSP-E using osmotic shock through a liquid biphasic flotation (LBF) system, having concluded that protein recovery of $92.98 \%$ with a separation efficiency of $64.91 \%$, partition coefficient of 1.47 and a volume ratio of 9 could be achieved using osmotic shock, whereas without osmotic shock the corresponding values were of only $84.84 \%, 69.68 \%, 1.89$ and 2.96 .

Although simple, the major drawbacks of this technique are that it takes longer than other processes such as autoclaving and microwave irradiation $[32,64]$, being economically unfeasible on a large scale [65].

\subsubsection{Enzymatic Methods}

Enzymatic cell lysis is a high-selective method for cell disruption that requires low energy and operates at mild conditions [66]. The commercial enzymes such as cellulases, proteases, lysozyme and glucanases are vastly employed and commonly used in the immobilized form to increase their lifetime and stability, preventing reduction in catalytic activity [27]. The main drawbacks of using enzymes compared to mechanical or chemical methods are the long process time, low production capacity and the possible product inhibition. In addition, the high cost of the enzymes limits their applications in a microalgae biorefinery [21]. Liang et al. [55] tested the combination of ultrasound with enzymatic lysis (snailase and trypsin) for lipid extraction in three microalgae species, achieving the maximum lipid yield of $49.82 \%$ in Chlorella vulgaris, $46.81 \%$ in Scenedesmus dimorphus and $11.73 \%$ in Nannochloropsis sp. Zhang et al. [56] achieved 86.4\% of lipid recovery in Scenedesmus sp. using a mixture of enzymes (cellulase, xylanase and pectinase), also increasing the fatty acid methyl esters (FAME) yield compared to the untreated biomass. However, despite improving the lipid yield from Scenedesmus sp., in the study by Zhang et al., the enzymes were used just as pretreatment followed by an organic solvent extraction, while Liang et al. used a more sustainable method based on enzyme-assisted aqueous extraction. Regarding to recent patents approaching solventless extraction of microalgae biomolecules, Bai et al. [67], US patent $\mathrm{n}^{\circ} 10196600 \mathrm{~B} 2$, described a method to induce self-lysis in microalgae cells (e.g., Chlorella sp., Micractinium sp., Tetraselmis sp., Isochrysis galbana and Dunaliella sp.). The active substance for self-lysis induction was extracted from Bacillus thuringienses ITRI-G1 suspension by vacuum distillation and isolated by high-performance liquid chromatography (HPLC). Once mixed with microalgal cells, the active substance triggers biochemical responses that induce self-lysis. The cell disruption effectiveness was estimated in terms of released-protein content by $\mathrm{A}_{280 \mathrm{~nm}}$ (absorbance at $280 \mathrm{~nm}$ ) measurements. After one hour of use of the active substance the absorbance $\left(\mathrm{A}_{280 \mathrm{~nm}}\right)$ was four-fold greater (approximately 1.6) when compared to control (approximately 0.4 ). The results also demonstrated an increase in protein concentration (of almost two-fold) by mixing the active substance without stirring, which represents a desirable economic aspect.

Table 2 shows several cell disruption methods (mechanical, physical and nonmechanical) employed for processing a range of microalgae species and obtaining target bioproducts. 
Table 2. Methods employed for microalgal cell disruption and components extraction.

\begin{tabular}{|c|c|c|c|c|}
\hline Species & Description $^{a}$ & Cell Disruption Method & Target Bioproduct & Main Results \\
\hline \multirow{6}{*}{$\begin{array}{l}\text { Arthrospira } \\
\text { (Spirulina) sp. }[15,68]\end{array}$} & \multirow{6}{*}{$\begin{array}{l}\text { Filamentous cyanobacteria, no } \\
\text { heterocystes or alkinetes, helical shape. } \\
\text { Cell wall composed by four layer (L-I } \\
\text { and III: fibrillar material, L-II: } \\
\text { peptidoglycan and L-IV: } \\
\text { lipopolysaccharides) [69] }\end{array}$} & $\begin{array}{l}\text { Milling in a ball jar with porcelain balls } \\
\text { at } 60 \mathrm{rpm} \text {, for } 120 \mathrm{~min}\end{array}$ & \multirow{3}{*}{$\begin{array}{l}\text { Phycocyanin and phenolic } \\
\text { compounds }\end{array}$} & 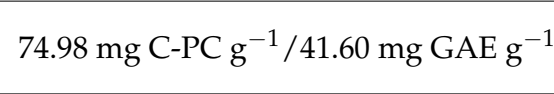 \\
\hline & & $\begin{array}{c}\text { Microwave oven } 2450 \mathrm{MHz} \text { and } 1400 \mathrm{~W} \text {, } \\
2 \mathrm{~min}\end{array}$ & & $85.43 \mathrm{mg} \mathrm{C}-\mathrm{PC} \mathrm{g}^{-1} / 41.90 \mathrm{mg} \mathrm{GAE} \mathrm{g}^{-1}$ \\
\hline & & $\begin{array}{c}\text { Autoclaving } 121^{\circ} \mathrm{C} \text { and } 200 \mathrm{kPa} \text {, } \\
\text { for } 30 \mathrm{~min}\end{array}$ & & $1.17 \mathrm{mg} \mathrm{C}-\mathrm{PC} \mathrm{g}^{-1} / 41.55 \mathrm{mg} \mathrm{GAE} \mathrm{g}^{-1}$ \\
\hline & & $\begin{array}{c}\text { Sonication } 20 \% \text { power at } 35 \mathrm{kHz}, 50 \% \\
\text { duty cycle for } 7 \mathrm{~min}\end{array}$ & \multirow{3}{*}{ Phycocyanin } & $94.89 \%\left(\mathrm{P}_{\mathrm{f}}: 6.17\right)$ \\
\hline & & Homogenisation, speed 3 for $3 \mathrm{~min}$ & & $89.51 \%\left(\mathrm{P}_{\mathrm{f}}: 5.59\right)$ \\
\hline & & Freeze-thawing, $8 \mathrm{~h}$ & & $77.10 \%\left(\mathrm{P}_{\mathrm{f}}: 4.15\right)$ \\
\hline \multirow{6}{*}{ Botryococcus braunii [16] } & \multirow{6}{*}{$\begin{array}{l}\text { Non-filamentous, pyriform shape }(7 \times \\
14 \mu \mathrm{m}) \text {, colonies can vary from } 30 \mu \mathrm{m} \text { to } \\
>2 \mathrm{~mm}) \text {, cell wall composed by } \\
\text { polysaccharide with hydrocarbons } \\
\text { between [70] }\end{array}$} & Ultrasonication 5-60 kHz, for 3-15 min & \multirow{6}{*}{ Lipids } & $28-30 \%$ \\
\hline & & $\begin{array}{l}\text { Bead-beating at } 2000-3500 \mathrm{psi}, \\
\text { for } 15 \mathrm{~min}\end{array}$ & & $35-38 \%$ \\
\hline & & $\begin{array}{l}\text { Autoclave } 121^{\circ} \mathrm{C} \text { and } 0.15 \mathrm{MPa}, \\
5-90 \mathrm{~min}\end{array}$ & & $38-40 \%$ \\
\hline & & French-press 500-3000 psi & & $29-43 \%$ \\
\hline & & $\begin{array}{l}\text { Microwave oven } 0-1250 \mathrm{~W} \text { at } 20-200^{\circ} \mathrm{C} \text {, } \\
\text { under } 2450 \mathrm{MHz} \text {, for } 0-25 \mathrm{~min}\end{array}$ & & $25-50 \%$ \\
\hline & & $\begin{array}{l}\text { Osmotic Shock } 0-2 \mathrm{MNaCl} \text {, stirred for } 1 \\
\text { min and maintained } 48 \mathrm{~h}\end{array}$ & & $18-22 \%$ \\
\hline Chlorella vulgaris [55] & $\begin{array}{l}\text { Non-filamentous, spherical format ( } 3-4 \\
\mu \mathrm{m}) \text { and cell wall composed by } \\
\text { extracellular polysaccharides, } \\
\text { rhamnose, galactose, xylose [ } 59]\end{array}$ & $\begin{array}{l}\text { Ultrasound at } 600 \mathrm{~W} \text { for } 15 \mathrm{~min} \text { and } \\
\text { enzymatic lysis with snailase and } \\
\text { trypsin }\left(37^{\circ} \mathrm{C}, \mathrm{pH} 4.0\right)\end{array}$ & Lipids & $49.82 \%$ \\
\hline
\end{tabular}


Table 2. Cont

\begin{tabular}{|c|c|c|c|c|}
\hline Species & Description $^{a}$ & Cell Disruption Method & Target Bioproduct & Main Results \\
\hline \multirow{4}{*}{ Haematococcus pluvialis [17] } & \multirow{4}{*}{$\begin{array}{l}\text { Non-filamentous. Cell wall mostly } \\
\text { composed by cellulose. Under favorable } \\
\text { growth conditions can present flagella } \\
\text { and a gelatinous thick extracellular } \\
\text { matrix. In motile cells, the lost of the } \\
\text { flagella result in changes on the } \\
\text { extracellular matrix that become } \\
\text { amorphous. Under stress conditions the } \\
\text { cells can transform into cysts or } \\
\text { aplanospores and a secondary wall is } \\
\text { formed [71] }\end{array}$} & $\begin{array}{l}\text { Freezing-thawing in liquid nitrogen, } \\
\text { during } 5 \text { cycles }\end{array}$ & \multirow{4}{*}{ Astaxanthin } & \multirow{4}{*}{$38-95 \%$} \\
\hline & & $\begin{array}{l}\text { Dimethyl sulfoxide and glass beads. } \\
\text { Cycles until pellet became colorless } \\
\text { ( } 5 \text { or } 10 \text { cycles) }\end{array}$ & & \\
\hline & & $\begin{array}{c}\text { PEF }\left(1 \mathrm{kV} \mathrm{cm}^{-1}, 50 \mathrm{~ms}, 50 \mathrm{~kJ} \mathrm{~kg}^{-1}\right) \\
+6 \mathrm{~h} \text { incubation }\end{array}$ & & \\
\hline & & Thermal treatment at $70^{\circ} \mathrm{C}$ for $1 \mathrm{~h}$ & & \\
\hline Nannochloropsis sp. [55] & $\begin{array}{l}\text { Non-filamentous, round shape }(2-4 \mu \mathrm{m}) \\
\text { and cell wall composed by glucose, } \\
\text { cellulose, mannans, rhamnose, fucose, } \\
\text { galactose and galacturonic acid [59] }\end{array}$ & $\begin{array}{l}\text { Ultrasound at } 600 \mathrm{~W} \text { for } 15 \mathrm{~min} \text { and } \\
\text { enzymatic lysis with snailase and } \\
\text { trypsin } \\
\left(37^{\circ} \mathrm{C}, \mathrm{pH} 4.0\right)\end{array}$ & \multirow{2}{*}{ Lipids } & $11.73 \%$ \\
\hline \multirow[t]{2}{*}{$\begin{array}{l}\text { Scenedesmus dimorphus [55] } \\
\text { Scenedesmus sp. }[56,72]\end{array}$} & \multirow[t]{2}{*}{$\begin{array}{l}\text { Non-filamentous, bean shape (10-12 } \\
\mu \mathrm{m} \text { ) and cell wall composed by } \\
\text { crystalline glycoprotein and algaenan } \\
\text { (non-hydrolyzable structure) [59] }\end{array}$} & $\begin{array}{l}\text { Cellulase }\left(20 \mathrm{mg} \mathrm{g}^{-1}\right), \mathrm{xylanase}(14 \mathrm{mg} \\
\left.\mathrm{g}^{-1}\right) \text { and pectinase }\left(10 \mathrm{mg} \mathrm{g}^{-1}\right) \text { at } 45^{\circ} \mathrm{C} \\
\text { and } \mathrm{pH} 4.4 \text { and chemical treatment with } \\
\text { chloroform:methanol }(1: 1 \mathrm{v} / \mathrm{v})\end{array}$ & & 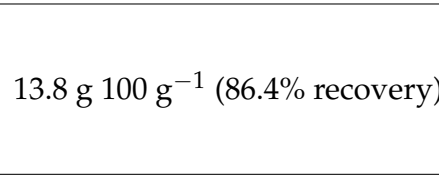 \\
\hline & & $\begin{array}{l}\text { Hydrothermal treatment with water } \\
1: 13(w / v) \text { at } 147^{\circ} \mathrm{C} \text { for } 40 \mathrm{~min}\end{array}$ & Glucose & $14.22 \mathrm{~g} \mathrm{~L}^{-1}(89.32 \%$ recovery $)$ \\
\hline
\end{tabular}


Table 2. Cont.

Pleiomorphic diatom with poorly silicified cell walls (up to 10 silica bands), can present different shapes (fusiform, triradiate and cruciform) and the size range from 8-25 $\mu \mathrm{m}[59,77]$

\section{Species}

$$
\text { Description }^{\text {a }}
$$

Non-filamentous cyanobacteria

Although uncommon, it may be

Synechocystis sp. [73]

surrounded by a thin, colorless,

diffluent mucilaginous envelope. Cell

wall composed by a peptidoglycan

layer and an outer membrane (mostly

proteins and lipopolysaccharide) [74]

\section{Cell Disruption Method}

Ultrasound at $20-25 \mathrm{kHz}$ for $30 \mathrm{~min}$

$$
\text { (cycles of } 5 \mathrm{~s} \text { on } / 5 \mathrm{~s} \text { off) }
$$

Bead milling in glass beads for $10 \mathrm{~min}$

with cycles of $30 \mathrm{~s}$ vortexing and $30 \mathrm{~s}$

$$
\text { cooling on ice }
$$

Silicon carbide (200-450 mesh) grinding

3 cycles of 1 min grinding $/ 1$ min cooling on ice

3 cycles of freezing at $-80^{\circ} \mathrm{C}$ for $10 \mathrm{~min}$ and thawing at $37^{\circ} \mathrm{C}$ for $5 \mathrm{~min}$

5 cycles $\cdot \mathrm{min}^{-1}$ of sonication at $20 \mathrm{kHz}$ for $15 \mathrm{~min}$

Carotenoids

Soaking in ethanol at room temperature for $24 \mathrm{~h}$, Cryogrinding in a ceramic

mortar with liquid nitrogen and

deionized water, Planetary micro mill,

2 cycles of $4 \mathrm{~min}$ at $400 \mathrm{rpm}$ with $1 \mathrm{~min}$

of relaxation time, Potter homogenizer

Phaeodactylum tricornutum $[75,76]$ with ethanol for 1-5 $\mathrm{min}$, Homogenise at $18,000 \mathrm{rpm}, 10-180 \mathrm{~s}, 2-4$ cycles and

$30 \mathrm{~s}$ of relaxation time, Sonication,

$2-4$ pulsed cycles (10 s on $/ 5 \mathrm{~s}$ off)

$30 \%$ power $(500 \mathrm{~W})$ and 30 s relation

time, Mixer mill stainless steel grinding

jars or propylene grinding tubes,

bead-beating with ethanol for 1-4 min

\section{Target Bioproduct}

$94.4 \%$ cell disruption efficiency

$1.88 \mathrm{mg} \mathrm{mL}^{-1}$ protein

$54.4 \%$ cell disruption efficiency $1.09 \mathrm{mg} \mathrm{mL}^{-1}$ protein

93.3\% cell disruption efficiency $1.89 \mathrm{mg} \mathrm{mL}^{-1}$ protein

$43.3 \%$ cell disruption efficiency $0.19 \mathrm{mg} \mathrm{mL}^{-1}$ protein

$81.7 \mu \mathrm{g} \mathrm{g}^{-1} \beta$-carotene; $679.2 \mu \mathrm{g} \mathrm{g}^{-1}$ zeaxanthin; $5163.4 \mu \mathrm{g} \mathrm{g}^{-1}$ fucoxanthin

$$
\text { and } 2-4 \text { cycles. }
$$

Positive effect in cell disruption: sonication and mixer mill (both) Negative effect in cell disruption: soaking, cryiogrinding and Potter homogeniser bead-beating, planetary micro mill, 
Table 2. Cont.

Species Description $^{\text {a }}$
Cell Disruption Method

Ankistrosdesmus: Non-filamentous with

mucilaginous envelopes present or

absent, commonly find as colonies,

fusiform cells (curved, straight or

Mixed microalgae feedstock

(Ankistrosdesmus sp

Chlamydomonas sp.,

sigmoid), smooth cell wall [78]

Chlamydomonas, Chlorella and

Scenedesmus: Non-filamentous.

Chlamydomonas present a complex
Acid hydrolysis $\mathrm{H}_{2} \mathrm{SO}_{4} 1.5 \mathrm{M}$ at 80-90

${ }^{\circ} \mathrm{C}$ for $80 \mathrm{~min}$
Carbohydrates

$10.2 \mathrm{~g}$ maltose, $103.1 \mathrm{~g}$ glucose and

$68.8 \mathrm{~g}$ xylose/galactose per $\mathrm{Kg}$ of

dry biomass and Scenedesmus sp.) [52]

multilayer cell wall composed by $20-25$

proteins and glycoproteins (rich in

hydroxyproline) [79]

Micromonas: Flagellate with absent

cell wall

Nitzschia sp.: diatom that can occur in

Freeze-dried mixed biomass three cell types: normal (fusiform

(95\% Scenedesmus obliquus, straight or curved, no longer than $35 \mu$ ),

$4 \%$ Scenedest

and $1 \%$ Nitzschia sp.) [53]

oval ( $8 \mu$ long and 3-4 $\mu$ broad) or

triradiate (arms varying from 6

Enzymatic lysis with cellulase (from

to10 $\mu$ ) [80]

Freeze-dried mixed biomass

(61\% Aphanothece sp. and

Aphanothece sp.: cells can occur in many

Tricoderma reesei), $\beta$-glucosidase (from

shapes (oval, ellipsoidal, straight or

Aspergillus niger), $\mathrm{pH} 4.9,50{ }^{\circ} \mathrm{C}$ and 300

rpm for $48 \mathrm{~h}$

Carbohydrates (sugars) and

byproducts (alcohols and

organic acids)

Total sugars: $9.84 \mathrm{~g}$ per $100 \mathrm{~g}$ of dry biomass

Total byproducts: $1.09 \mathrm{~g} \mathrm{~L}^{-1}$

slightly curved) with absent of

mucilaginous envelope
Total sugars: $0.02 \mathrm{~g}$ per $100 \mathrm{~g}$ of dry biomass

Total byproducts: $7.38 \mathrm{~g} \mathrm{~L}^{-1}$

${ }^{a}$ Complementary data available on: http:/ / algaebase.org. PEF: pulsed electric field. C-PC: C-phycocyanin. GAE: gallic acid equivalents. PUFA: polyunsaturated fatty acids. Pf: purity factor. 
Larrosa et al. [15] improved phycocyanin extraction in Arthrospira platensis using microwave irradiation from $85.43 \mathrm{mg} \cdot \mathrm{g}^{-1}$ to $74.98 \mathrm{mg} \cdot \mathrm{g}^{-1}$ by milling and $1.17 \mathrm{mg} \mathrm{g}{ }^{-1}$ by autoclaving. The expressive low content of phycocyanin obtained by autoclaving is probably due to protein denaturation caused by the operational conditions. In addition, Chia et al. [68] showed a variation in phycocyanin recovery ranging from $77.10 \%$ to $94.89 \%$ and purity from 4.15 to 6.17 in A. platensis by changing the cell-disruption method (e.g., freeze-thawing, microwave, homogenization and sonication). Zhou et al. [73] also tested different cell disruption methods in Synechocyst is sp. for protein release, achieving the highest cell disruption with ultrasound ( $94.4 \%)$ followed by silicon carbide grinding $(93.3 \%)$, bead-milling (54.4\%) and freeze-thawing (43.3\%). Thus, as shown in Table 2, the efficiency of the cell-disruption method can significantly change according to the microalgae species and the properties of the target product. In this sense, the use of two cell-disruption methods is a way to enhance cell disruption efficiency and, consequently, the recovery of the target biocompound [81]. Moreover, it is important to emphasize that besides the extraction efficiency and quality of bioproducts, the chosen cell-disruption method can also directly influence the subsequent purification steps.

\section{Extraction Methods}

As stated before, microalgal cells may contain many compounds of interest and value that must be separated from other less valuable components. Several different extraction methods can be used combined with cellular disruption or directly applied over the whole cell. These include solvent extraction, using organic solvents, ionic liquids, deep eutectic solvents, supercritical fluids, among others.

\subsection{Organic Solvent Extraction}

The use of organic solvents is a well-known technique for the extraction of microalgae biomolecules. Frequently, this kind of extraction is associated with a previous celldisruption step to facilitate the access of solvent to inner cell compounds, thus enhancing the extraction yield. Several filled patents available on the US Patent database have also reported the use of organic solvents for microalgae biocomponents extraction (Table 3). 
Table 3. Recent US-granted patents approaching cell disruption, extraction and recovery of microalgae biomolecules using organic solvents (FAME: fatty acid methyl esters).

\begin{tabular}{|c|c|c|c|}
\hline Patent Purpose & Pretreament & Solvents & Main Results \\
\hline $\begin{array}{c}\text { Production and extraction of } \\
\text { squalene from microalgae of } \\
\text { the Thraustochytriales sp. } \\
\text { Family [82] }\end{array}$ & $\begin{array}{l}\text { Alkaline lysis } \\
(\mathrm{KOH} 45 \%)\end{array}$ & $\begin{array}{l}\text { Hexane/ } \\
\text { ethanol }\end{array}$ & $6.7 \mathrm{~g} \mathrm{~L}^{-1}$ of squalene content \\
\hline $\begin{array}{l}\text { Production of pure microalgae } \\
\text { extracts to modulate the } \\
\text { metabolism of human skin } \\
\text { and hair follicles [83] }\end{array}$ & - & $\begin{array}{l}\text { Methanol/ } \\
\text { ethanol/ } \\
\text { ethyl acetate }\end{array}$ & $\begin{array}{l}\text { Achieved an effective } \\
\text { treatment using a composition } \\
\text { comprising from } 0.001 \text { to } 35 \% \\
\text { of dry matter content of an } \\
\text { extract of Monodus sp. }\end{array}$ \\
\hline $\begin{array}{l}\text { Method for extraction of } \\
\text { lipids in an organic phase and } \\
\text { sugars by hydrolysis [84] }\end{array}$ & Homogenization & Acetone & $\begin{array}{l}\text { Results suggest that it is } \\
\text { possible to achieve an } \\
\text { industrial-scale extraction } \\
\text { yield of } 96.3 \% \text { of total lipids in } \\
\text { the starting wet algal biomass }\end{array}$ \\
\hline $\begin{array}{l}\text { Biodiesel production and } \\
\text { isolation of several valuable } \\
\text { co-products from the marine } \\
\text { alkenone-producing } \\
\text { microalgae Isochrysis [85] }\end{array}$ & - & $\begin{array}{l}\text { n-hexane/ethanol or } \\
\text { methanol/ } \\
\text { dichloromethane or } \\
\text { toluene/acetonitrile }\end{array}$ & $\begin{array}{l}\text { 27:8:1 (FAME:alkenones: } \\
\text { fucoxanthin) co-production }\end{array}$ \\
\hline
\end{tabular}

Pora et al. [82] achieved a maximum squalene content of $6.7 \mathrm{~g} \cdot \mathrm{L}^{-1}$ from microalgae of the Thraustochytriales sp. family by organic solvent extraction (Table 3). This result is up to 2.5 -fold other results that have been reported in the literature, which are between 0.9 to $2.46 \mathrm{~g} \cdot \mathrm{L}^{-1}$ in species such as Aurantiochytrium sp. $18 \mathrm{~W}-13 \mathrm{a}\left(0.9\right.$ and $\left.1.29 \mathrm{~g} \cdot \mathrm{L}^{-1}\right)$, extracted by chloroform:methanol $(2: 1, v / v)$ [86] and n-hexane containing 10\% of chloroform, respectively [87], Schizochytrium mangrovei PQ6 $\left(1.01 \mathrm{~g} \cdot \mathrm{L}^{-1}\right)$ extracted by n-hexane:diethyl ether:acetic acid $(70: 30: 4, v / v / v)$ [88], S. limacinum SR21 $\left(0.9 \mathrm{~g} \cdot \mathrm{L}^{-1}\right.$ of squalene produced in bioreactor) extracted by chloroform:methanol (2:1, v/v) [89] and Aurantiochytrium sp. BR-MP4-A1(2.46 g. $\left.\mathrm{L}^{-1}\right)$ extracted with hexane (3 cycles) after saponification with $10 \%$ $\mathrm{KOH}(w / w)$ and $75 \%$ ethanol $(v / v)$ [90]. In other granted patent, Massetti et al. [84] results suggest that it is possible to achieve $96.3 \%$ of lipids extraction yield from Nannochloropsis $\mathrm{sp}$. at industrial scale. Their invention comprises the use of acetone, a preferable organic solvent when compared to common solvents such as hexane and chloroform, due its lower toxicity. Despite the use of organic solvent, the perspective of almost $96 \%$ of extraction yield is quite expressive. This value was predicted from an experiment that resulted in $281 \mathrm{~g}$ of lipids, which means $27.94 \%$ of volatile solids present in the starting wet biomass ( $66.72 \%$ in which $29 \%$ is related to lipids). Du et al. [91] maximized the lipid extraction yield in an oleaginous microalgae Neochloris oleabundans. In this work, the authors achieved a maximum lipid extraction yield of $61.3 \%$ dry weight in fresh water stressed (nitrogen limitation) cultivations after multistage extractions (four extractions) with n-ethylbutylamine as solvent. Moreover, some publications have reported less than $50 \%$ of lipid yield in different microalgae species using more recent technology based on supercritical $\mathrm{CO}_{2}$ $\left(\mathrm{Sc}-\mathrm{CO}_{2}\right.$ ) extraction, $20 \%$ Nannochloropsis oculata $\left(\mathrm{Sc}-\mathrm{CO}_{2}, 450\right.$ bar), $40 \%$ Chlorella vulgaris (Sc- $\mathrm{CO}_{2}$ and ethanol 10\% v/v, 250 bar) [92], 11.1\% Tetraselmis sp. (Sc-CO -300 bar) [93] and $12.1 \%$ Nannochloropsis sp. (Sc-CO 2,550 bar) [94].

Classical organic solvent-based techniques for microalgae biocompounds extraction and recovery, mostly lipids, include the Bligh and Dyer (B\&D) method [95], Folch method [96] and Soxhlet method [97]. The B\&D and Folch methods are quite similar techniques widely used for lipid extraction. Folch is a two-step method, which firstly employs chloroform/methanol (2:1 ratio) as solvents to homogenize lipids. The homogenate is filtered and lipids separated in a second step, which comprises washing of the crude oil extract, with at least 5-fold volume 
of water. It is a time-consuming technique that requires large amounts of solvent. In order to solve the disadvantages of the Folch method, the B\&D examined the chloroform-methanolwater phase diagram, proposing a single-step method. Briefly, the homogenate obtained in the chloroform/methanol mixture must be a monophasic system, forming a bi-phase when mixed with water. The chloroform phase contains the lipids and the other phase is composed by methanol, water and non-lipid components.

Soxhlet is a classical technique proposed by Franz von Soxhlet in 1879, that comprises a Soxhlet apparatus in which lipids are extracted from biomass by exhausting reflux in organic solvent, commonly n-hexane or petroleum ether. Despite being a simple and scalable technology, it also is time consuming and requires a large solvent amount. Beyond that, the extraction yield is low, probably due to inefficient polar lipid extraction [98].

Despite being well-established techniques, conventional solvents are toxic and not aligned with environmental and human health concerns. In this sense, Breil et al. [99] studied several potential solvents to substitute chloroform (e.g., 2-methyltetrahydrofuran (MeTHF), cyclopentyl methyl ether (CPME), ethyl acetate (EtOAc), ethyl lactate, dimethyl carbonate (DMC), p-cymene, d-limonene and $\alpha$-pinene) and methanol (e.g., ethanol and isopropanol) in B\&D and Folch methods for lipid extraction. The classical chloroform/methanol/water system still is more selective than the tested solvents. However, their study suggests that the combination of ethyl acetate/ethanol, followed by the addition of water enriched with $\mathrm{KCl}$ and ethyl acetate is a suitable option. In addition, Gorgich et al. [100] increased lipid recovery using methyl tert-butyl ether (MTBE), which is less hazardous than classical solvents (e.g., chloroform and hexane), in three microalgae species compared to modified B\&D method (chloroform:methanol:water, 1:2:0.8 (v/v)). The highest yield and also the most expressive difference between methods were observed in lipid extraction from Chlorella zofingiensis, resulting in $34.06 \%$ by MTBE and $26.68 \%$ by the B\&D method. On the other hand, Ruecker et al. [101], US patent $n^{\circ} 10329515 B 2$, described a solventless lipid-extraction process based on alkaline treatment for cell disruption with potassium hydroxide $(\mathrm{KOH})$, followed by sequential aqueous phase separation, achieving process performance and bioproduct quality comparable to the traditional solvent extraction with hexane.

\subsection{Alternative Solvents Extraction}

By contrast with conventional solvents, alternative solvents are supposed to have lower environmental, safety and health impacts [102]. Some examples of alternative solvents are bio-based solvents such as terpenes, ionic liquids, deep eutectic solvents, and liquid polymers. One of the most well studied liquid polymers is polyethylene glycol (PEG), a biodegradable polymer widely used in aqueous two-phase systems [103]. Focusing on recent developments, this section will discuss the use of ionic liquids and deep eutectic solvents.

Ionic liquids (ILs) are organic salts with melting points of $100{ }^{\circ} \mathrm{C}$ or below. However, not all ILs have "green" characteristics and must be avoided. For a better understanding Bubalo et al. [104] present a general description of the potential environmental risks of ILs. These substances are usually composed of an organic cation and an anion that can be organic or inorganic. ILs have great thermal stability, solvating power and non-volatile characteristics due to their high enthalpies of vaporization $\left(\Delta_{\mathrm{vap}} \mathrm{H}\right)$. There are several possible combinations between cations and anions for ILs synthesis; it is estimated up to $10^{18}$ combinations.

This feature significantly broadens the ILs applicability and it has attracted great interest from the modern scientific community, especially for extraction and separation of biocompounds [103,105]. Table 4 shows some examples of ILs used as assistant for microalgal components extraction. 
Table 4. Ionic liquids used for microalgae biomolecules extraction.

\begin{tabular}{|c|c|c|c|}
\hline Microalgae Species & Ionic Liquid & Abbreviation & $\begin{array}{c}\text { Target } \\
\text { Component }\end{array}$ \\
\hline Neochloris oleoabundans [106] & $\begin{array}{l}\text { 1-butyl-3-methylimidazolium } \\
\text { tetrafluoroborate } \\
\text { 1-butyl-3-methylimidazolium } \\
\text { methyl sulfate } \\
\text { 1-butyl-3-methylimidazolium } \\
\text { dicyanamide } \\
\text { 1-butyl-3- methylimidazolium } \\
\text { chloride }\end{array}$ & 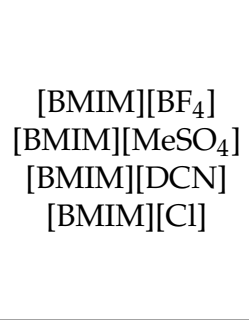 & Lipids \\
\hline $\begin{array}{c}\text { Chlorella vulgaris and Spirulina } \\
\text { platensis [107] }\end{array}$ & $\begin{array}{c}\text { 1-ethyl-3-methylimidazolium } \\
\text { acetate } \\
\text { choline L-arginate } \\
\text { choline glycinate } \\
\text { choline L-lysinate } \\
\text { choline L-phenyl-alaninate }\end{array}$ & $\begin{array}{c}{[\mathrm{Emim}][\mathrm{OAc}]} \\
{[\mathrm{Ch}][\mathrm{ARG}]} \\
{[\mathrm{Ch}][\mathrm{GLY}]} \\
{[\mathrm{Ch}][\mathrm{LYS}]} \\
{[\mathrm{Ch}][\mathrm{PHE}]}\end{array}$ & Carbohydrates and lipids \\
\hline Haematococcus pluvialis [35] & $\begin{array}{l}\text { ethanolammonium caproate } \\
\text { diethanolammonium caproate } \\
\text { triethanolammonium caproate }\end{array}$ & $\begin{array}{l}{[\mathrm{EAC}]} \\
{[\mathrm{DEAC}]} \\
{[\mathrm{TEAC}]}\end{array}$ & Astaxanthin \\
\hline Scenedesmus sp. [108] & $\begin{array}{l}\text { triethylammonium hydrogen } \\
\text { sulfate } \\
\text { 1-butylpyridinium hydrogen } \\
\text { sulfate } \\
\text { 1-butylpyridinium } \\
\text { dihydrogen phosphate }\end{array}$ & $\begin{array}{c}{\left[\mathrm{HNEt}_{3}\right]\left[\mathrm{HSO}_{4}\right]} \\
{[\mathrm{BPy}]\left[\mathrm{HSO}_{4}\right]} \\
{[\mathrm{BPy}]\left[\mathrm{H}_{2} \mathrm{PO}_{4}\right]}\end{array}$ & Lipids \\
\hline Chlorella vulgaris [36] & $\begin{array}{l}\text { 1-octyl-3-methylimidazolium } \\
\text { bis(trifluoromethanesulfonyl) } \\
\text { imide } \\
\text { 1-octyl-3-methylimidazolium } \\
\text { acetate }\end{array}$ & $\begin{array}{l}{[\text { Omim }][\mathrm{NTf} 2]} \\
{[\mathrm{Omim}][\mathrm{OAc}]}\end{array}$ & Lipids \\
\hline
\end{tabular}

ILs and deep eutectic solvents (DES) have several similar properties, such as thermal stability, conductivity and low volatility, but differ in the sources and chemical processes involved in their synthesis. DES present a cheaper and easier synthesis and a range source of potential starting materials, being capable of overcoming some ILs' limitations like high cost, purification steps and toxicity [109]. DES are formed by hydrogen bond interactions between a hydrogen bond acceptor (e.g., choline chlorine or choline acetate) and a hydrogen bond donor (e.g., carboxylic acids, amides, amines and alcohols), presenting a final melting point lower than each independent component used in their synthesis. There are also the so-called natural deep eutectic solvents (NADES), when the compounds are primary metabolites (e.g., organic acids, amino acids, sugar, among others) [110,111]. Table 5 summarizes some examples of deep eutectic solvents applied for lipids and polyphenolic compounds extraction from microalgae. 
Table 5. Deep eutectic solvents (DES) used to extract microalgae-based compounds.

\begin{tabular}{|c|c|c|c|c|c|c|}
\hline $\begin{array}{l}\text { Microalgae } \\
\text { Species }\end{array}$ & DES & $\begin{array}{c}\text { Hydrogen } \\
\text { Bond Acceptor }\end{array}$ & $\begin{array}{l}\text { Hydrogen } \\
\text { Bond Donor }\end{array}$ & $\begin{array}{c}\text { Monomer Ratio } \\
\text { (mol:mol) }\end{array}$ & Target Product & Yield (\%) \\
\hline \multirow{4}{*}{$\begin{array}{c}\text { Chlorella } \\
\text { vulgaris [112] }\end{array}$} & Ch-Gly & \multirow{4}{*}{$\begin{array}{l}\text { Choline } \\
\text { chloride }\end{array}$} & Glycerol & $1: 2$ & \multirow{4}{*}{$\begin{array}{l}\text { Polyphenolic } \\
\text { compounds }\end{array}$} & $5.27^{\mathrm{a}}$ \\
\hline & Ch-EG & & Ethylene glycol & $1: 4$ & & $7.19^{\mathrm{a}}$ \\
\hline & Ch-PDO & & $\begin{array}{c}1-3- \\
\text { propanediol }\end{array}$ & $1: 4$ & & $9.19^{a}$ \\
\hline & Ch-BDO & & 1-4-butanediol & $1: 4$ & & $9.87^{\mathrm{a}}$ \\
\hline \multirow{4}{*}{$\begin{array}{c}\text { Chlorella sp. and } \\
\text { Chlorococcum sp. } \\
\text { [113] }\end{array}$} & $\mathrm{Ch}-\mathrm{Fa}$ & & Formic acid & $1: 3$ & \multirow{4}{*}{ FAME } & $9.12 / 9.00$ \\
\hline & Ch-Aa & Choline & Acetic acid & $1: 3$ & & $13.91 / 11.5$ \\
\hline & $\mathrm{Ch}-\mathrm{Oa}$ & chloride & Oxalic acid & $1: 1$ & & $10.35 / 9.40$ \\
\hline & $\mathrm{Ch}-\mathrm{Pa}$ & & $\begin{array}{l}\text { Propanedioic } \\
\text { acid }\end{array}$ & $1: 1$ & & $10.53 / 9.52$ \\
\hline \multirow{3}{*}{$\begin{array}{l}\text { Chlorella sp. } \\
\text { [110] }\end{array}$} & $\mathrm{aCh}-\mathrm{O}$ * & Choline & Oxalic acid & $1: 2$ & \multirow{3}{*}{ FAME } & $16.41^{b}$ \\
\hline & aCH-EG * & chloride & Ethylene glycol & $1: 2$ & & $15.32^{b}$ \\
\hline & $\mathrm{aU}-\mathrm{A}$ * & Urea & Acetamide & $1: 2$ & & $10.53^{b}$ \\
\hline
\end{tabular}

* aqueous, ${ }^{a}$ mg GAE.g ${ }^{-1}$ biomass, ${ }^{b}$ corresponding to $\mathrm{mg}$ linoleic acid (C18:2) g biomass. GAE: gallic acid equivalent. FAME: fatty acid methyl esters.

\subsection{Supercritical Fluid Extraction}

Supercritical fluid extraction (SFE) has been increasingly employed, especially in the food and pharmaceutical industries, as a green and contamination-free extractive method [114]. SFE combines extraction and separation by strictly controlling process parameters such as temperature, pressure, flow rate and processing time. Therefore, this selective capacity allows products with greater purity and yields to be obtained [115].

Substances in conditions of temperature and pressure above its critical point are called supercritical fluids (SCFs), which combine properties of liquids and gases in an effective way. In this state, supercritical fluids show some interesting properties, such as lower viscosity than liquids and ability to better dissolve substances than gases and with more diffusive power. In addition, SCFs can work for some difficult or impossible extractions using organic solvents. Knez et al. [116] made a critical review about SCFs as solvents for the future, concluding that from an environmental point of view, SCFs are a feasible alternative to conventional organic solvents, capable of providing products with high purity and low energy consumption, once the high pressure technologies are advancing.

Concerning the extraction of microalgae biomolecules, SFE has been widely used mainly for recovery of polyunsaturated fatty acids (PUFAs), pigments and vitamin, in which the most commonly employed solvent is $\mathrm{sc}-\mathrm{CO}_{2}$, pure or associated with some other co-solvent. Yang et al. [117] developed a method based on a solid matrix-supported sc- $\mathrm{CO}_{2}$ for $\gamma$-linolenic acid (GLA) extraction from Arthrospira platensis, reaching more than $34.5 \%$ GLA of the total fatty acids and $98 \%$ of extraction efficiency. On the other hand, Feller et al. [118] compared sc- $\mathrm{CO}_{2}$ with subcritical n-butane extraction of $\omega-3$ and $\omega-6$ fatty acids in Phaeodactylum tricornutum, Nannochloropsis oculata and Porphyridium cruentum, demonstrating that in all cases subcritical n-butane extracted more PUFAs, $\omega-3$ and $\omega-6$, than the other solvent. In fact, they realized that $\mathrm{sc}^{\mathrm{CO}} \mathrm{O}_{2}$ is more selective for saturated fatty acids (SFA) extraction. However, $\mathrm{sc}-\mathrm{CO}_{2}$ also extracted more total carotenoids in two of the three tested species.

Another way to improve extraction performance is by combining supercritical fluid with a co-solvent. In this regards, Chronopoulou et al. [119] evaluated $\mathrm{sc}-\mathrm{CO}_{2}$ extraction of several biomolecules (alpha-tocopherol, phylloquinone, gamma-tocopherol, retinol, canthaxanthin, phytofluene and lutein) from Tetradesmus obliquus microalgae. In this work, the authors obtained some satisfactory results by using limonene and methanol as $\mathrm{sc}-\mathrm{CO}_{2}$ co-solvents. For example, the use of these co-solvents enabled the extraction of canthaxanthin and lutein that was not possible under only sc- $\mathrm{CO}_{2}$ conditions, achieving the maximum extraction yield of $16.14 \%$ and $1.25 \%$, respectively. Table 6 summarizes the 
yields and operating conditions for the supercritical extraction of different components from various microalgae species.

Table 6. Supercritical extraction of different components from microalgae species.

\begin{tabular}{|c|c|c|c|c|c|c|c|}
\hline Microalgae Species & Solvent(s) & $\mathrm{T}\left({ }^{\circ} \mathrm{C}\right)$ & P (bar) & $\begin{array}{l}\text { Flow Rate } \\
\left(\mathrm{g} \mathrm{min}^{-1}\right)\end{array}$ & $\begin{array}{c}t \\
(\min )\end{array}$ & $\begin{array}{c}\text { Target } \\
\text { Compound }\end{array}$ & $\begin{array}{l}\text { Extraction } \\
\text { Yield (\%) }\end{array}$ \\
\hline $\begin{array}{l}\text { Chlorella saccharophila } \\
\text { [59] }\end{array}$ & $\mathrm{sc}-\mathrm{CO}_{2}$ & 73.0 & 241 & 3 SLPM & 60 & FAME & 17.60 \\
\hline Spirulina platensis [120] & $\mathrm{sc}-\mathrm{CO}_{2}+\mathrm{EtOH}$ & 55.0 & 78.6 & $52.83^{a}$ & 75 & Vitamin E & 8.08 \\
\hline Spirulina platensis [121] & $\mathrm{sc}-\mathrm{CO}_{2}+\mathrm{EtOH}$ & 55.0 & 80 & $52.83^{a}$ & 75 & Pigments & 7.94 \\
\hline $\begin{array}{l}\text { Nannochloropsis sp. } \\
\text { [94] }\end{array}$ & $\mathrm{sc}-\mathrm{CO}_{2}$ & 75.0 & 550 & 14.48 & 100 & Lipids & 12.08 * \\
\hline \multirow{8}{*}{$\begin{array}{l}\text { Tetradesmus obliquus } \\
\text { [119] }\end{array}$} & \multirow{6}{*}{$\mathrm{sc}-\mathrm{CO}_{2}+\mathrm{MeOH}$} & 60.0 & 0.25 & \multirow{7}{*}{-} & \multirow{7}{*}{90} & Phylloquinone & 302.74 \\
\hline & & \multirow{2}{*}{50.0} & \multirow{3}{*}{0.35} & & & Canthaxanthin & 16.14 \\
\hline & & & & & & Lutein & 1.25 \\
\hline & & \multirow{4}{*}{40.0} & & & & $\gamma$-tocopherol & 137.43 \\
\hline & & & \multirow{3}{*}{0.30} & & & $\alpha$-tocopherol & 200.15 \\
\hline & & & & & & Retinol & 543 \\
\hline & $\mathrm{sc}-\mathrm{CO}_{2}+$ limonene & & & & & Phytofluene & 142.65 \\
\hline & & & & & & & $\left(\mathrm{mg} \mathrm{g}^{-1} \mathrm{dw}\right)$ \\
\hline \multirow{2}{*}{$\begin{array}{l}\text { Scenedesmus almeriensis } \\
\text { [122] }\end{array}$} & \multirow{2}{*}{$\mathrm{sc}-\mathrm{CO}_{2}$} & \multirow{2}{*}{65.0} & 0.55 & 14.48 & \multirow{2}{*}{120} & Lutein & $2.97^{* *}$ \\
\hline & & & 0.40 & 7.24 & & Lipids & 15.02 \\
\hline $\begin{array}{l}\text { Nannochloropsis } \\
\text { gaditana [123] }\end{array}$ & $\mathrm{sc}-\mathrm{CO}_{2}$ & 65.0 & 250 & 7.24 & 100 & EPA & 11.50 \\
\hline $\begin{array}{l}\text { Nannochloropsis oculata } \\
\text { [118] }\end{array}$ & \multirow{3}{*}{$\mathrm{sc}-\mathrm{CO}_{2}$} & \multirow{3}{*}{40.0} & \multirow{3}{*}{300} & \multirow{3}{*}{$0.02^{\mathrm{a}}$} & \multirow{3}{*}{120} & \multirow{3}{*}{ Lipids } & 15.60 \\
\hline $\begin{array}{l}\text { Phaeodacthylum } \\
\text { tricornutum [118] }\end{array}$ & & & & & & & 14.70 \\
\hline $\begin{array}{l}\text { Porphyridium cruentum } \\
\text { [118] }\end{array}$ & & & & & & & 4.50 \\
\hline
\end{tabular}

SLPM: Standard liter per minute. EtOH: ethanol. MeOH: methanol. FAME: fatty acid methyl esters. EPA: eicopentaenoic acid. ${ }^{\text {a }}$ Calculated according to data available in the referenced paper. ${ }^{*} 19.5 \%$ purity; ${ }^{* *}$ approximately $34 \%$ purity.

Ferreira et al. [124] studied the environmental and economic aspects of a biorefinery from Nannochloropsis sp., comparing the use of Soxhlet extraction (with n-hexane) and SFE for oil and other co-products extraction. The study showed that despite consuming more energy (262 MJ.MJprod $\left.{ }^{-1}\right)$ and generate more $\mathrm{CO}_{2}$ emissions $\left(17 \mathrm{~g} \cdot \mathrm{MJprod}^{-1}\right)$ than Sohxlet extraction (220 M.MJprod ${ }^{-1}$ and $14 \mathrm{~g} \cdot \mathrm{MJprod}^{-1}$, respectively) in oil production, SFE is more economically feasible once this technology allows the co-extraction of high-value pigments. Thus, SFE presented a final cost (e.g., cultivation and downstream processes) of $365 € \cdot \mathrm{kg}_{\text {oil }}{ }^{-1}$ while the Soxhlet extraction costs were estimated in $661 € \cdot \mathrm{kg}_{\mathrm{oil}}{ }^{-1}$. Moreover, there are many specifications currently available for supercritical fluid extraction (Table 7), proving the advancement of this technology in the market. 
Table 7. Examples of supercritical fluids extraction equipment available.

\begin{tabular}{|c|c|c|}
\hline Company & Scale & Specifications \\
\hline \multirow{3}{*}{ ExtrateX Supercritical Fluid Innovation ${ }^{a}$} & Laboratory & $\begin{array}{l}\text { Volume: } 50-1000 \mathrm{~mL} ; \mathrm{CO}_{2} \text { pump: } 0-100 \mathrm{~g} \mathrm{~min}^{-1} \\
\text { Pressure: } 0-100 \mathrm{bar} \text {; Temperature: up to } 150{ }^{\circ} \mathrm{C} \\
\text { Co-solvent pump: } 24 \mathrm{~mL} \mathrm{~min}^{-1} \text { at } 400 \mathrm{bar}\end{array}$ \\
\hline & Small production & $\begin{array}{l}\text { Volume: } 5-20 \mathrm{~L} ; \mathrm{CO}_{2} \text { pump: } 0-24 \text { or } 0-40 \mathrm{~kg} \mathrm{~h}^{-1} \\
\text { Pressure: } 0-350 \text { bar; Temperature: } 0-150{ }^{\circ} \mathrm{C} \\
\text { Co-solvent pump: } 100 \mathrm{~mL} \min ^{-1} \text { at } 350 \mathrm{bar}\end{array}$ \\
\hline & Large production & $\begin{array}{l}\text { Volume: } 25-100 \mathrm{~L} ; \mathrm{CO}_{2} \text { pump: } 0-150 \text { or } 0-300 \mathrm{~kg} \mathrm{~h}^{-1} \\
\text { Pressure: } 0-350 \text { bar; Temperature: } 0-150{ }^{\circ} \mathrm{C} \\
\text { Co-solvent pump: } 30 \mathrm{~L} \mathrm{~h}^{-1} \text { at } 350 \text { bar }\end{array}$ \\
\hline $\begin{array}{c}\text { Joda Technology Co. } \\
{\text { (15 specifications available })^{b}}^{\text {b }}\end{array}$ & Small to large production & $\begin{array}{l}\text { Pressure: } 400-500 \text { bar; Flow rate: } 60-16,000 \mathrm{~L} \mathrm{~h}^{-1} \\
\text { Area: } 10-700 \mathrm{~m}^{2} \text {; Height: } 2.5-16 \mathrm{~m} \\
\text { Capacity of raw material: } 10-20 \mathrm{~kg} \text { or less to } 5-12 \text { ton }\end{array}$ \\
\hline \multirow{4}{*}{ Tradematt (Henan) Industry Co., Ltd. ${ }^{c}$} & Small production & $\begin{array}{l}\text { Extractor: } 10 \mathrm{~L} \times 2, \leq 50 \mathrm{MPa} \text {; } \\
\text { Separator: } 5 \mathrm{~L} \times 2 / 3, \leq 16 \mathrm{MPa} \\
\text { Temperature: } \leq 85^{\circ} \mathrm{C} \text {; Power: } 20 \mathrm{~kW} \\
\mathrm{CO}_{2} \text { flow rate: } 100 \mathrm{~L} \mathrm{~h}^{-1}\end{array}$ \\
\hline & \multirow{3}{*}{ Large production } & $\begin{array}{l}\text { Extractor: } 25 \mathrm{~L} \times 2, \leq 40 \mathrm{MPa} \\
\text { Separator: } 15 \mathrm{~L} \times 2 / 3, \leq 16 \mathrm{MPa} \\
\text { Temperature: } \leq 85^{\circ} \mathrm{C} \text {; Power: } 30 \mathrm{~kW} \\
\mathrm{CO}_{2} \text { flow rate: } 300 \mathrm{~L} \cdot \mathrm{h}^{-1}\end{array}$ \\
\hline & & $\begin{array}{l}\text { Volume: } 700 \mathrm{~L} \times 3 \text {; Pressure: } 320-500 \text { bar } \\
\text { Flowrate: } 4000 \mathrm{~L} \mathrm{~h}^{-1} \text {; Area: } 500 \mathrm{~m}^{2} \\
\text { Capacity of raw material: } 1.5-3.5 \text { ton }\end{array}$ \\
\hline & & $\begin{array}{l}\text { Volume: } 1500 \mathrm{~L} \times 3 \text {; Pressure: } 320-500 \text { bar } \\
\text { Flowrate: } 800 \mathrm{~L} \mathrm{~h}^{-1} \text {; Area: } 600 \mathrm{~m}^{2} \\
\text { Capacity of raw material: } 3.5-8 \text { ton }\end{array}$ \\
\hline Green Mill Supercritical ${ }^{d}$ & Small production & $\begin{array}{l}\mathrm{CO}_{2} \text { pump: } 100-500 \text { gm } \mathrm{min}^{-1} \text {, pressure: } 7500 \text { psia } \\
\text { Extractor: } 7.5 \mathrm{~L} \text {; Separator: } 3.3 \mathrm{~L} \\
\text { Power requirements: } 200 \mathrm{~V}, 60 \mathrm{~Hz}, 1 \text { phase, } \\
\sim 67 \text { A maximum and } 14.7 \mathrm{~kW} \text { maximum }\end{array}$ \\
\hline
\end{tabular}

Websites: ${ }^{a}$ www.extratex-sfi.com; ${ }^{b}$ www.joda-tech.com; ${ }^{c}$ www.cntradematt.com; ${ }^{d}$ www.greenmillsupercritical.com.

\section{Analysis Method}

The chromatographic methods use the differences in the characteristics of molecules in a mixture to separate them, according to properties such as adsorption (liquid-solid), partition (liquid-solid), affinity and molecular weights. There are several types of chromatography and the effectiveness of each one will depend on the nature of the molecule to be separated [125].

\subsection{Supercritical Fluid Chromatography}

Similar to other chromatographic techniques, supercritical fluid chromatography (SFC) is capable of detecting and separating the components of a given sample. In addition, SFC combines some advantages of both gas chromatography (GC) and high-performance liquid chromatography (HPLC) and can be particularly useful for substances that decompose at high temperatures in GC or have some undetectable functional groups in HPLC systems [126]. Abrahamsson et al. [127] used the combination of SFC and SFE for carotenoid extraction and separation from Scenedesmus sp., being able to maximize the extraction of all compounds, except violaxanthin, by adding $10 \%$ ethanol as co-solvent to sc- $\mathrm{CO}_{2}$. These authors obtained $72.9 \mu \mathrm{g}$-astaxanthin, $59.9 \mu \mathrm{g} \cdot \beta$-carotene, $436.1 \mu \mathrm{g}$-lutein, $670.8 \mu \mathrm{g} \cdot$ neoxanthin and $89.6 \mu \mathrm{g} \cdot$ zeaxanthin per gram of freeze dried algae, in $60 \mathrm{~min}$ of extraction at $300 \mathrm{bar}, 60^{\circ} \mathrm{C}$ and $2 \mathrm{~mL} \cdot \mathrm{min}^{-1}$ of total flow. Additionally, they achieved a 
repeatability of $2.4 \%$ relative standard deviation (RSD) and intermediate-precision of $6.4 \%$ RSD, in extracts of SFE using co-solvent. These results are quite similar to those reported for carotenoids, obtained through the conventional technique of HPLC analysis [128].

\subsection{Column Chromatography}

Column chromatography is solid-liquid adsorption chromatography. This technique consists of a column packed with an adsorbent, commonly alumina $\left(\mathrm{Al}_{2} \mathrm{O}_{3}\right)$ or silica gel $\left(\mathrm{SiO}_{2}\right)$, forming the stationary phase. The sample carried by the mobile phase passes through the column and the molecules are separated based on its polarity [129]. Silica gel is the most common adsorbent used in stationary phase for column chromatography, although for some applications alumina has been shown to be more suitable. For a better understanding of the particularities of each compound (i.e., silica gel and alumina) this subject was reviewed by Nawrocki [130,131] and Claessens and van Straten [132]. Anyhow, silica gel has been successfully reported for microalgae bio-oil purification, including compounds such as tridocosahexaenoyl glycerol (tri-DHA) [133], mono and polyunsaturated fatty acids [134] from the commercial oil DHASCO ${ }^{\circledR}$ extracted from Crypthecodinium cohnii, $\gamma$-linolenic acid from S. platensis [135], eicosapentaenoic and arachidonic acids (EPA and AA) from Porphyridium cruentum [136] and carotenoids such as fucoxanthin from Nitzschia sp. [137].

\section{Hydroxyapatite Chromatography}

Hydroxyapatite is a calcium phosphate commonly used in chromatographic columns for protein and DNA separation. The adsorption of proteins on hydroxyapatite involves anionic and cationic exchanges and, in order to facilitate this process, the proteins are generally eluted by increasing phosphate gradient [138]. In this sense, several authors have reported the use of hydroxyapatite chromatography for phycobiliproteins separation in various microalgae and red algae species, such as Rhodella violacea [139], Arthrospira maxima [140], Corallina elongata [141], A. platensis [142,143] and Porphyra yezoensis Ueda [144]. Other reported applications of hydroxyapatite chromatography separations involve recovery of enzyme from Pavlova pinguis [145] and phosphoprotein from transgenic Chlamydomonas reinhardtii [146].

\subsection{Gel Permeation Chromatography}

Gel permeation chromatography (GPC) is a size-exclusion chromatography widely used for macromolecules separation. In this technique, the hydrophobic stationary phase is composed of inert particles with small pores. The sample is continuously injected into the chromatographic column, carried by the mobile phase that is commonly an organic solvent. The smaller the size of the molecule, the longer the retention time in the column, as long as these small molecules permeate the pores of the stationary phase. Larger molecules, in contrast, pass straight through the column, presenting shorter retention times. Thus, GPC gives the molecular weight distribution of a sample $[125,147]$. For microalgae, this technique is particularly useful in the characterization of polysaccharides $[148,149]$ that can reach levels in the range of 8-64\% DW [150] and polyhydroxyalkanoates [151].

\subsection{Ion-Exchange Chromatography}

The ion-exchange chromatography (IEX) uses the difference between the charge properties of the molecules to promote their separations. Therefore, it is used to separate biomolecules with ionizable groups, such as proteins, nucleic acids, peptides, among others. Higher selectivity can be achieved by manipulating some process parameters such as $\mathrm{pH}$, which is capable of altering the surface net charge of charged biomolecules. It is worth mentioning that the correlation between surface net charge and $\mathrm{pH}$ is unique for each protein, allowing high levels of specificity in this application [152,153].

Chen et al. [154] developed a single-step C-phycocyanin (C-PC) extraction from S. platensis using stirred fluidized bed ion exchange chromatography. The biomass was 
pre-treated with ultrasonication and from $10 \%$ dry weight of the disrupted cells the group reached $59.4 \%$ of C-PC recovery yield with 3.0 of purity factor $\left(\mathrm{A}_{615 \mathrm{~nm}} / \mathrm{A}_{280 \mathrm{~nm}}\right)$. However, by combining ultrafiltration with IEX as a strategy to enhance purity of B-phycoerythrin from Porphyridium cruentum, Tang et al. [155] achieved a purification factor $\left(A_{545 \mathrm{~nm}} / \mathrm{A}_{280 \mathrm{~nm}}\right)$ of 5.1 , which is considered of analytical grade, with $68.5 \%$ yield.

\subsection{Affinity Chromatography}

Affinity chromatography relies on very specific reversible interactions to separate complex mixtures. The target molecule carried by the mobile phase binds to the ligand immobilized in the stationary phase by affinity. The recovery of these molecules is accomplished by further washing and elution steps. In order to select the most appropriate matrix to compose the stationary phase, besides the specific interaction of the target molecule, some other characteristics should be taken into account, such as high physical and chemical stability, low adsorption of undesirable molecules and good properties to maintain the mobile phase flow throughout the whole process [156].

\subsection{Thin-Layer Chromatography}

In thin-layer chromatography (TLC), it is obligatory for the mobile phase to be a liquid, but the stationary phase, the 'thin-layer', can be solid or a solid with a certain amount of liquid [157]. This technique is widely used for lipid and phospholipids separation [158-160], although PUFAs oxidation still occurs due to the long period of oxygen contact [161]. TLC has also been reported for fucoxanthinol purification [162], separation of final products of biocatalytic transformation [163], antioxidants [164] and for biodiesel characterization [165].

\subsection{High-Performance Liquid Chromatography}

Through the use of high pressure, which forces the solvent to pass through the closed column, packed with small particles, high-performance liquid chromatography (HPLC) can achieve high separation resolution. The smaller the particle size that compose the stationary phase, the greater the separation efficiency, however, high pressure is required. The HPLC system consists of a mobile phase reservoir, mobile phase pumping system, sample injection system, chromatographic column and detection, control, acquisition and data recording system [166]. In microalgae-based biocomponents, HPLC has been extensively reported for carotenoids [128,167-169], fatty acid composition [170,171] and phenolic acids profile [172]. Recently, Hussain et al. [173] published the results of their research discussing the use of chiral and achiral ionic liquids (ILs) in HPLC to enantiomeric separation, an important field for biopharmaceuticals. Although the use of chiral ILs is not a fully-elucidated technology, it has great potential to replace the conventional chiral phases used in HPLC. Unlike IL-based phases, the conventional ones have several limitations, such as instability at high temperatures, low solubility, high ultraviolet (UV) absorptivity and high cost $[105,174]$. Figure 3 shows the most suitable mode of the HPLC method according to biomolecule properties. 


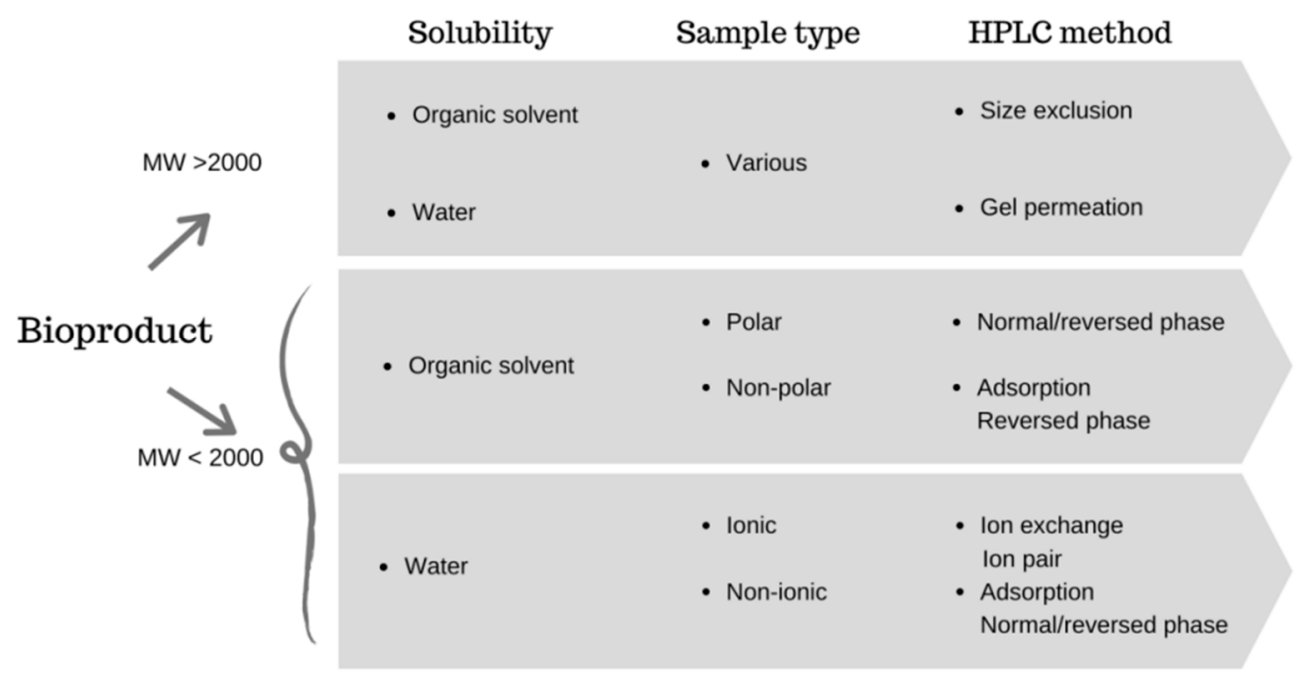

Figure 3. Selection of high-performance liquid chromatography (HPLC) methods for biomolecule separation according to bioproduct properties. MW: molecular weight [129].

\subsection{Counter Current Chromatography}

In addition to HPLC, another liquid chromatography technique is countercurrent chromatography (CCC), in which both mobile and stationary phases are liquid. The principle of this technique is based on the difference in the affinity of the solutes of a mixture for these phases, and, unlike what the name suggests, there is no countercurrent in this process [175].

Recently, Fábryová et al. [176] developed a new protocol integrated with multiinjection high-performance countercurrent chromatography (HPCCC) for lutein extraction in Chlorella vulgaris biomass. The extract with the highest lutein concentration was obtained in the lower phase of a biphasic solvent system composed of n-heptane, ethanol and water (5:4:1.5, $v / v / v)$, which was used for both extraction and the mobile phase for HPCCC lutein isolation $\left(3.20 \mathrm{mg} \cdot \mathrm{g}^{-1} \mathrm{DW}\right)$. In $2 \mathrm{~g}$ of this C. vulgaris extract, $60 \mathrm{mg}$ lutein with $92 \%$ of purity was obtained, which was subsequently taken to gel permeation chromatography resulting in $50 \mathrm{mg}$ of lutein with $97 \%$ purity. Earlier, Cheel et al. [177] reported the yield of $4 \mathrm{mg}$ of nostotrebin 6 (NOS-6) with $99 \%$ of purity from $100 \mathrm{mg}$ of crude extract obtained from Nostoc sp. NOS-6 has been described as an inhibitor of acetylcholinesterase and butyrylcholinesterase, enzymes with great relevance in studies to treat Alzheimer's disease.

Another CCC-based methodology is the high-speed counter-current chromatography (HSCCC), which is based on hydrodynamic equilibrium. In this technique, while one phase is pumped through the column, the other liquid phase is retained by centrifugal force. This model has high separation efficiency and furthermore, circumvents the sample adsorption problem presented by other chromatographic methods using a solid matrix [178].

HSCCC is mostly reported for plants, fruits or herbal biocomponents-based extraction [179]. However, for microalgae-based biomolecules, HSCCC has been reported for separation of polysaccharides [180], squalene [181], carotenoids [182,183] and lipopeptides [184], in this last case associated with HPLC.

\subsection{Gas Chromatography}

Gas chromatography (GC) is widely used for detecting and separating volatile molecules. In this system, the stationary phase can be composed of a solid (gas-adsorption) or a nonvolatile liquid absorbed on an inert powder (gas-liquid partition) whereas the sample is carried through the column by an inert gas. Thus, the molecules are separated due to their different migration velocity in the chromatographic column [185]. Table 8 shows the applicable chromatographic method according to the type of biomolecule. 
Table 8. Comparison of gas chromatography (GC) applicability and the main chromatographic methods for biomolecules separation. Adapted from Ahuja [129] (GC: gas chromatography, HPLC: high-performance liquid chromatography, IEX: ion-exchange chromatography, TLC: thin-layer chromatography).

\begin{tabular}{|c|c|c|c|c|c|c|}
\hline \multirow{2}{*}{$\begin{array}{c}\text { Biomolecule } \\
\text { Type }\end{array}$} & \multicolumn{6}{|c|}{ Chromatographic Methods } \\
\hline & GC & HPLC & IEX & TLC & $\begin{array}{c}\text { Size- } \\
\text { Exclusion }\end{array}$ & Adsorption \\
\hline Hydrophilic & & $X$ & $x$ & $x$ & $X$ & \\
\hline Hydrophobic & $x$ & $x$ & & $x$ & $x$ & $x$ \\
\hline Ionic & & $x$ & $x$ & $x$ & & \\
\hline Non-ionic & $x$ & $x$ & & $X$ & $x$ & $x$ \\
\hline Volatile & $x$ & & & & & \\
\hline Non-volatile & & $x$ & $x$ & $x$ & $x$ & $x$ \\
\hline Simple & & & $x$ & $x$ & & \\
\hline Complex & $x$ & $x$ & & & $x$ & $x$ \\
\hline
\end{tabular}

In microalgae-based products, GC is mostly reported as a methodology for fatty acid methyl esters (FAME) separation in lipid extracts [31]. Over time, several variants of conventional GC were developed in order to improve separation resolution, and broaden the field of application. Examples include the two-dimensional GC, which is composed of two subsequent columns containing different stationary phases [186] that can be performed as GC-GC, when only selected fractions are re-injected in the second column, or GC $\times$ GC, when the sample is continuously re-injected [187]. Another example is the pyrolysis gas chromatography mass spectrometry (Py-GC/MS), in which the components are separated on a fused silica column and detected by mass spectrometer that can work in continuous or pulse modes, according to heating mechanism [188]. Py-GC/MS presents some advantages over other techniques, such as Fourier-transform infrared (FTIR) and thermogravimetric analysis (TGA), including the detection of products with low molar weight, without heating rates limitation and providing more complete information about gaseous products. Thus, Py-GC/MS has been used in the analysis of microalgae pyrolysis products aiming biofuel production [189].

\section{Separation and Purification Methods}

After the extraction, the biomolecules are usually mixed with either solvent or combined in a single phase, making it necessary to separate the compounds of interest from those that are of least interest or to remove impurities, which lower their value or introduce some type of toxicity. Thus, it is generally necessary to apply separation methods to purify the extracted compounds. These include electrophoresis, membrane separation, ultracentrifugation, etc., whose characteristics, advantages and disadvantages will be presented.

\subsection{Electrophoresis}

Electrophoresis uses the charge of the molecules to make them migrate through an electric field. This technique is commonly used for proteins and other macromolecules separation. Unlike GPC, where all particles are forced through the column, in electrophoresis, smaller particles migrate through the column pores, while larger particles remain almost immobile. Moreover, high-resolution separations can be achieved by two-dimensional electrophoresis (2DE), which was previously reported to solve more than 1000 proteins from Escherichia coli bacterium in a single experiment [190]. The advantage of this approach is that in the first moment, the molecules are separated based on their charges and then according to their molar masses [191]. In the literature it is reported that electrophoresis and 
2DE have been used in water-soluble and insoluble proteins resolution from microalgae, such as Porphyridium cruentum [192], Haematococcus pluvialis [193] and Chlorella protothecoides [194]. Alternatively, Lipkens et al. [195], US patent n ${ }^{\circ}$ 9556411B2, described a method based on ultrasound and acoustophoresis for Dunaliella salina's harvesting, lipid extraction and separation. The process comprises three sequential chambers; in each one a specific ultrasonic transducer forms acoustic waves perpendicular to the flow in order to accomplish harvesting, lipid extraction and lipid separation, respectively.

\subsection{Membrane Separation Processes}

Membrane processes allow separation of different compounds based on their size or charge (e.g., electromembrane). In conventional membrane filtration, while molecules larger than the pore size of membranes are retained, the lower molecules pass through the membrane pores, regardless of their nature, that is, without selectivity.

\subsubsection{Ultrafiltration}

Ultrafiltration (UF) is widely used for macromolecules concentration and buffer exchange. For example, by using reduced pore size membranes (i.e., 1-100 nm) and mild temperature conditions, high retention of proteins and enzymes can be achieved. However, unlike chromatographic methods, UF has no selectivity and has the disadvantages of being susceptible to fouling and absorption of target compounds during filtration. On the other hand, it is a low-cost technique and easy to scale up for commercial applications [196].

Chaiklahan et al. [197] evaluated the purification of a crude C-PC extracted from Spirulina sp. in two steps. First, performing microfiltration with 5 and $0.8 / 0.2 \mu \mathrm{m}$ pore size membranes at 150 and $100 \mathrm{~mL} \cdot \mathrm{min}^{-1}$, respectively, and then, membrane ultrafiltration with $50 \mathrm{kDa}$ MWCO (Molecular Weight Cut Off) at $69 \mathrm{kPa}$ and $75 \mathrm{~mL} \cdot \mathrm{min}^{-1}$ flowrate. Under these conditions, the purity ratio increased from $0.54 \pm 0.19$ (before UF) to $1.07 \pm 0.01$, being considered as food grade.

Still in a pigment purification approach, Gómez-Loredo et al. [198] studied ultrafiltration as a complementary method to alcohol-salt aqueous two-phase systems (ATPS) for fucoxanthin (i.e., carotenoid) purification, achieving approximately $16 \%$ reduction in impurities. In addition, they noted that by increasing the concentration of ethanol in the biphasic system, more contaminants were trapped in the membrane. Thus, in this case, fouling turns out to be a desirable event.

\subsubsection{Electromembrane Filtration}

Electromembrane filtration (EF) is an alternative to conventional membrane filtration. The great advantage of EF is to promote separation by charge and molecular weight without requiring pressure, being more selective than the conventional membranes [199]. Kim et al. [200] also proved electromembrane filtration as a useful tool for harvesting Chlorella sp. KR-1, improving fourfold (6.47) the concentration factor (CF) when electricity was applied. Meanwhile, the maximum CF achieved was 1.32 and 1.56, without electricity and by commercial polyvinylidene (PVDF) membrane, respectively.

\subsection{Ultracentrifugation}

The differentiated sedimentation of molecules, according to their densities and under the influence of gravity (g-force), is the basic principle of particles separation by centrifugation. In laboratory scale, the g-force of ultracentrifugation can reach values of up to $200,000 \times g$, being able, for example, to remove impurities (e.g., chlorophyll, cell debris) in an extract of C-phycocyanin [201] and to estimate molecular weight of enzymes and proteins from microalgae [202]. However, for this last purpose ultracentrifugation is already outdated. Also, it is an energy-intensive procedure. 


\subsection{Aqueous Two-Phase Systems}

In aqueous two-phase systems (ATPS) the phases are generally formed by the combination of polymer/polymer or polymer/salt as phase-forming components. However, the combination of alcohol/salt has also been widely used due to the easy of alcohol removal by evaporation. This technique can be used to purify several biomolecules such as pigments, proteins, enzymes, amino acids, antibodies, etc. [203]. The principle of the ATPS method is the mass transfer mechanisms involved in the equilibrium and phase separation of a mixture. The phase diagram of an ATPS is distinct and provides the optimal operating conditions (e.g., temperature, $\mathrm{pH}$ and concentration of the phase-forming components). Additionally, the physicochemical properties and concentration of the crude sample, as well as tie line length (the length of the line joining the composition of the two phases in a phase diagram), phase volume ratio of the two phases and the presence of additives can also affect the partitioning effect of target molecules in liquid biphasic systems and must be taken into account [204]. A variant of this technique that has been widely used to purify molecules from microalgal biomass is the liquid biphasic flotation (LBF). This technique combines ATPS with solvent sublation (SS), which is based on the adsorption of molecules in bubbles surface in aqueous phase. Briefly, the target component is carried by bubbles to the top of the immiscible phase composed of the organic solvent. Then, the bubbles rupture, releasing the target molecules to be recovered in the upper zone of the column [203].

Table 9 shows some recent research about purification of microalgal biomolecules by LBF. Chew et al. [205] achieved almost 94\% recovery of C-PC in Spirulina platensis using PEG 4000 and (NH4) ${ }_{2} \mathrm{SO}_{4}$. Meanwhile, Chia et al. [68], members of the same group, improved recovery in $1 \%$ by replacing salt with $\mathrm{K}_{2} \mathrm{HPO}_{4}$ and optimizing the pretreatment parameters ( $20 \%$ power, $50 \%$ duty cycle and $7 \mathrm{~min}$ of irradiation time). However, the most interesting result was that the purity factor of C-PC almost quadrupled with these adaptations, increasing from 1.63 to 6.17 . The purity factor of C-PC extracts is generally given by the ratio $A_{615 n m} / A_{280 \mathrm{~nm}}$ (absorbance at 615 and $280 \mathrm{~nm}$ ), which correlates the presence of C-phycocyanin and other contaminating proteins. Purity factors above 4.0 are considered as analytical grade and can value more than US\$ 15 per mg [5]. Furthermore, Safaei et al. [206] reported four-step C-PC purification from Limnothrix sp. NS01, but achieving only 5.26 of purity. The steps included treatments with chitosan, activated charcoal, precipitation with ammonium sulfate and IEX. The genus Limnothrix includes filamentous cyanobacteria as well as Spirulina, which reinforces the importance of the results obtained by Chia et al. [68].

Table 9. Purification of microalgal biomolecules by liquid biphasic flotation.

\begin{tabular}{|c|c|c|c|c|c|c|c|}
\hline $\begin{array}{l}\text { Microalgae } \\
\text { Species }\end{array}$ & Pretreatment & $\begin{array}{c}\text { Type of } \\
\text { Polymers }\end{array}$ & Type of Salts & $\begin{array}{l}\text { Type of } \\
\text { Alcohol }\end{array}$ & Bioproduct & $\begin{array}{c}\text { Recovery } \\
(\%)\end{array}$ & $\begin{array}{l}\text { Purity } \\
\text { Factor }\end{array}$ \\
\hline $\begin{array}{l}\text { Chlorella } \\
\text { sorokiniana [207] }\end{array}$ & Ultrasonication & - & $(\mathrm{NH} 4)_{2} \mathrm{SO}_{4}$ & 2-propanol & Protein & 53.16 & - \\
\hline $\begin{array}{l}\text { Haematococcus } \\
\text { pluvialis [208] }\end{array}$ & $\begin{array}{l}\text { Mechanical } \\
\text { cell } \\
\text { disruption }\end{array}$ & - & $\mathrm{Na}_{2} \mathrm{CO}_{3}$ & 2-propanol & Astaxanthin & 104.28 & - \\
\hline $\begin{array}{l}\text { Spirulina platensis } \\
\text { [205] }\end{array}$ & Ultrasonication & PEG 4000 & $(\mathrm{NH} 4)_{2} \mathrm{SO}_{4}$ & - & C-PC & 93.50 & 1.63 \\
\hline $\begin{array}{l}\text { Spirulina platensis } \\
\text { [68] }\end{array}$ & Sonication & PEG 4000 & $\mathrm{~K}_{2} \mathrm{HPO}_{4}$ & - & C-PC & 94.89 & 6.17 \\
\hline
\end{tabular}

PEG: polyethylene glycol. C-PC: C-phycocyanin.

As shown in Table 9, LBF is always associated with a previous pretreatment step. However, it is possible to integrate electric cell disruption and LBF in just one step (i.e., extraction followed by purification), the so-called liquid biphasic electric flotation (LBEF) [209]. Koyande et al. [210] were able to increase separation efficiency (nearly 10\%) and protein recovery (nearly $20 \%$ ) by replacing LBF with LBEF in protein extraction from C. vulgaris. 
Nevertheless, other adaptations of the methodology have been explored, such as the use of ionic liquids (ILs) [211] or the combination of non-ionic surfactants and ionic liquids [212] in the biphasic systems formation.

\subsection{Three-Phase Partitioning}

Three-phase partitioning (TPP) is a simple method for protein purification. Briefly, $\mathrm{t}$-butanol and ammonium sulfate are added to an aqueous solution containing proteins. The ammonium sulfate promotes proteins precipitation and after mild centrifugation, proteins are concentrated in an intermediate zone between two immiscible phases: $\mathrm{t}$ butanol on top, and water in the bottom [213]. t-butanol is usually miscible in water, but in the presence of a certain amount of salt, such as ammonium sulfate, it becomes immiscible. In TPP, t-butanol increases protein buoyancy by acting as a co-precipitating agent and assisting in the triphasic formation [214]. Recently, Chia et al. [9] used a combination of TPP and LBF (method described in 5.4), the liquid triphasic flotation system (LTF), for protein recovery from Chlorella vulgaris biomass. In this last approach, LTF, the three phases are formed by a mixture of microalgal biomass, salt solution and t-butanol. The proteins are concentrated in the intermediate zone as well as in TPP and the air bubbles, also used in LBF, facilitate its extraction, reducing process time. In this work, they achieved approximately $90 \%$ of recovery and above $60 \%$ of separation efficiency.

\subsection{Ammonium Sulfate Precipitation}

The ammonium sulfate precipitation is a very well-established method applied to protein purification. By adding a salt into an aqueous solution containing the proteins, the salt dissociates and the water that once offered a great solvating power to proteins, solvates the dissociated ions preferably. Thus, the charges of the protein molecules tend to interact more, forming aggregates and precipitating, an effect called salting out. In addition, ammonium sulfate is usually chosen for this purpose due to its high water solubility and low cost [215]. Silva et al. [216] performed an experimental design to optimize some parameters (i.e., $\left(\mathrm{NH}_{4}\right)_{2} \mathrm{SO}_{4}$ concentration, volume and $\mathrm{pH}$ ) in an ammonium sulfate precipitation protocol for C-PC purification from Spirulina platensis. The highest C-PC purity factor achieved was 0.88 at $0-20 \% / 20-50 \%\left(\mathrm{NH}_{4}\right)_{2} \mathrm{SO}_{4}$ saturation, 0.52 (resuspension volume/initial volume) and $\mathrm{pH} 7.0$, with $83.8 \%$ of recovery. However, this methodology is generally used as a pre-purification step and it is often associated with chromatographic methods $[217,218]$ or membrane dialysis $[219,220]$. Muensean and Kim [221] tested the purification of $\beta$-glucosidase, from Trichoderma citrinoviride produced by Chlorella vulgaris, in three steps. First, they performed the ammonium sulfate precipitation and then passed the sample through a DEAE-Sepharose FF column. Finally, the enzymatic-concentrated sample was loaded onto a Sephacryl S-100 HR column. As expected, yield decreases with each step, but the specific activity of the enzyme and its purification increased more than 30-fold (5.53 to $168.74 \mathrm{U} \cdot \mathrm{mg}^{-1}$ and 4.55 to 138.72 , respectively). Later, Chen et al. [222] evaluated the purification of C-PC from S. platensis by ammonium sulfate precipitation, ion exchange chromatography and the combination of both. The best recovery was obtained with precipitation only $(91 \pm 2 \%)$, while the highest purity was obtained by combining both techniques $(4.33 \pm 0.10)$, in which the purity achieved with ammonium sulfate was $1.92 \pm 0.06$ and with chromatography $3.70 \pm 0.06$.

Table 10 summarizes the main advantages and disadvantages of several separation and purification methods described in Section 4. Among all advantages and disadvantages of each method, the chromatographic methods are still widely used at the laboratory scale. On the other hand, technologies based on multi-phase fractioning (e.g., aqueous two-phase and three-phase partitioning) despite being scalable demand large amounts of chemicals, generating environmental issues. 
Table 10. Main advantages and disadvantages of several methods for biomolecules separation and purification.

\begin{tabular}{|c|c|c|c|}
\hline Separation/Purification Method & Advantages & Disadvantages & References \\
\hline Supercritical fluid chromatography & $\begin{array}{l}\text { - } \quad \begin{array}{l}\text { Lower viscosity, higher diffusivity and high } \\
\text { efficiency }\end{array} \\
\text { - } \quad \begin{array}{l}\text { Fast time analysis and lower pressure drop } \\
\text { compared to liquid chromatography }\end{array} \\
\text { - } \quad \text { Can separate thermally labile compounds } \\
\text { - } \quad \text { Can use almost all HPLC and GC detectors }\end{array}$ & $\begin{array}{l}\text { Polarity of the mobile phase is limiting factor } \\
\text { (supercritical fluids is incapable of solubilizing } \\
\text { highly polar solutes) }\end{array}$ & {$[223,224]$} \\
\hline Gel permeation chromatography (GPC) & $\begin{array}{ll}- & \text { Rapid analysis time } \\
- & \text { Requires small amounts of sample } \\
- & \text { Suitable for separation of molecules with high MW } \\
& (>2000)\end{array}$ & $\begin{array}{ll}\text { - } & \text { Requires previous steps of sample preparation } \\
\text { - } & \text { GPC can only resolve solutes with molecular size } \\
\text { differing in } 10 \% \text { at least. } \\
\text { - } \quad \text { High equipment cost }\end{array}$ & {$[147,223]$} \\
\hline Ion-exchange chromatography & $\begin{array}{ll}\text { - } & \text { Applicable for several molecules } \\
\text { - } & \text { High purity levels with high efficiency }\end{array}$ & $\begin{array}{l}\text { Does not provide direct information of stationary } \\
\text { phase surface's events (response conditioned to the } \\
\text { interaction between solute, eluent and active sites } \\
\text { of resin) }\end{array}$ & [225] \\
\hline Thin-layer chromatography & $\begin{array}{ll}\text { - } & \text { Short time and simple operation/cheap technology } \\
\text { - } & \text { Can be used for direct analysis of crude samples } \\
\text { - } & \text { Performed at room temperature }\end{array}$ & 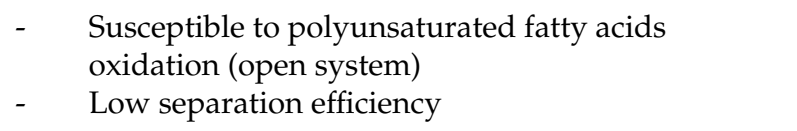 & {$[129,160,161,226]$} \\
\hline High-performance chromatography & $\begin{array}{ll}\text { - } & \text { Quantitative analysis with accuracy and precision } \\
\text { - } & \text { Great reproducibility and selectivity } \\
\text { - } & \text { Resolution of complex separations } \\
\text { - Not limited by volatility or thermal stability of the } & \text { sample } \\
\text { - } & \text { Sample recovery is relatively simple }\end{array}$ & $\begin{array}{ll}- & \text { Lower separation efficiency than capillary GC } \\
- & \text { No universal detector } \\
\text { - } & \text { Many operating parameters } \\
\text { (more complex operation) }\end{array}$ & {$[129,227]$} \\
\hline
\end{tabular}


Table 10. Cont.

\begin{tabular}{|c|c|c|c|}
\hline Separation/Purification Method & Advantages & Disadvantages & References \\
\hline Gas chromatography & $\begin{array}{l}\text { - } \begin{array}{l}\text { High resolution of components with short time } \\
\text { analysis }\end{array} \\
\text { - } \quad \text { Capable of analyze low amounts of sample }(\mu \mathrm{L}) \\
\text { - }\end{array}$ & $\begin{array}{l}\text { - } \quad \text { Limited to volatile compounds } \\
\text { - Commonly needs to be associated with mass } \\
\text { spectroscopy } \\
\text { - Not suitable for most polar, thermolabile or high } \\
\text { molecular weight compounds } \\
\text { - Not suitable for large-scale }\end{array}$ & {$[129,186]$} \\
\hline Ultrafiltration & $\begin{array}{ll}\text { - } & \text { Mild temperature conditions } \\
\text { - } & \text { Less energy consumption than other membrane } \\
\text { technologies } \\
\text { - } \quad \text { High retention of macromolecules }\end{array}$ & $\begin{array}{l}\text { - Conventional UF have a limitation of separation of } \\
\text { solutes with } 10 \text {-fold difference in size } \\
\text { - } \quad \text { Susceptible to membrane fouling }\end{array}$ & {$[196,198]$} \\
\hline Electromembrane filtration & $\begin{array}{l}\text { - More selective and with reduced fouling formation } \\
\text { compared to traditional membrane filtration } \\
\text { - Does not require pressure }\end{array}$ & - $\quad$ Requires additional energy & {$[199,200]$} \\
\hline Ultracentrifugation & Allows the separation of small biomolecules & $\begin{array}{ll}\text { - } & \text { Time consuming and sample loss } \\
\text { - } & \text { Expensive equipment that requires regular } \\
\text { maintenance } \\
\text { - } \\
\text { Incapable of processing various samples } \\
\text { simultaneously }\end{array}$ & [228] \\
\hline Aqueous two-phase systems & $\begin{array}{ll}\text { - } & \text { Low energy consumption and short processing time } \\
\text { - } & \text { High extraction efficiency } \\
\text { - } & \text { Simple operation and feasible for large-scale }\end{array}$ & $\begin{array}{l}\text { - } \quad \text { Requires large amounts of polymer in large scale } \\
\text { Environmental issues even recycling the } \\
\text { phase-forming polymer }\end{array}$ & {$[203,205,211]$} \\
\hline
\end{tabular}


Table 10. Cont.

Separation/Purification Method Advantages
Disadvantages

References

Simple operation with short processing time

Can be performed at room temperature

Mild conditions avoid protein denaturation

Purify and concentrate proteins (unlike

Three-phase partitioning

chromatographic methods, that dilute them)

Achieve high purity levels

- Can be used directly in cultures containing cell

debris without previous pretreatment

- $\quad$ Non expensive and feasible for large-scale
Requires organic solvents

Environmental concerns

- Commonly used as a pre-purification method,

frequently followed by chromatographic methods

or membrane filtration to achieve high purity levels
[216,218-220] 


\section{Conclusions}

Microalgal biomass is a rich source of biomolecules with applications in several industry sectors, such as food, pharmaceuticals and cosmetics. However, like any biotechnological process, it is necessary to establish strategies to make it economically viable. Recent developments using supercritical fluids, ionic liquid and deep eutectic solvents have shown potential substitutes for traditional extractive methods based on organic solvents. Furthermore, physicochemical treatments, such as supercritical fluid extraction, ultrasound-assisted extraction and pulsed electric fields are promising technologies for large-scale implementation, presenting high efficiency and producing extracts with a high purity level. In particular, the use of PEF treatments can be applied in both upstream, as a growth stimulator, and downstream processes to enhance extraction yield. Concerning biomolecule separation and purification, chromatographic methods are widely applied in laboratory scale, although, improvements in non-chromatographic methods based on multiphase systems have been extending their application and turned them scalable. However, the demand for large amounts of polymer or organic solvent is still the biggest drawback of these methods. Thus, greener technologies that combine high efficiency, selectivity and low energy demand, such as supercritical fluid extraction, are the preferable techniques applied in large-scale microalgae processes. Moreover, the recent developments applied to microalgal biomass have demonstrated not only the high value of microalgal biomass as feedstock for new biorefineries, but also the viability of a new bio-based economy that is more environmentally friendly and more sustainable. Despite the development of competitive bioproducts on the market still being a challenge and requiring great dedication from research centers, the transition from chemicals to bio-based products is an unquestionable trend worldwide.

Author Contributions: Conceptualization, P.S.C., W.G.M.J., T.M.M., N.S.C. and A.A.M.; data curation, P.S.C., W.G.M.J., T.M.M. and N.S.C.; writing—original draft preparation, P.S.C.; writing-review and editing, P.S.C., W.G.M.J., T.M.M., N.S.C. and A.A.M.; visualization, P.S.C., T.M.M. and N.S.C.; supervision, T.M.M., N.S.C. and A.A.M.; project administration, T.M.M., N.S.C.; funding acquisition, T.M.M., N.S.C. All authors have read and agreed to the published version of the manuscript.

Funding: This work was financially supported by Base Funding-UIDB/00511/2020 of Laboratory for Process Engineering, Environment, Biotechnology and Energy - LEPABE-funded by National funds through the FCT/MCTES (PIDDAC); Base Funding_UIDB/04730/2020 of Center for Innovation in Engineering and Industrial Technology, CIETI-funded by national funds through the FCT/MCTES (PIDDAC); project IF/01093/2014/CP1249/CT0003 funded by national funds through FCT/MCTES; project "EXTRATOTECA-Microalgae Extracts for High Value Products"—POCI-010247-FEDER-033784, funded by FEDER funds through COMPETE2020 - Programa Operacional Competitividade e Internacionalização (POCI) and by national funds (PIDDAC) through FCT/MCTES.

Acknowledgments: António Martins thanks FCT (Fundação para a Ciência e Tecnologia) for funding through program DL 57/2016-Norma transitória. Wilson Júnior thanks European Union's Horizon 2020 research and innovation programme under the Marie Skłodowska-Curie grant agreement number 867473 .

Conflicts of Interest: The authors declare no conflict of interest.

\section{References}

1. Morais Junior, W.G.; Gorgich, M.; Corrêa, P.S.; Martins, A.A.; Mata, T.M.; Caetano, N.S. Microalgae for biotechnological applications: Cultivation, harvesting and biomass processing. Aquaculture 2020, 528, 735562. [CrossRef]

2. Mata, T.M.; Martins, A.A.; Caetano, N.S. Microalgae for biodiesel production and other applications: A review. Renew. Sustain. Energy Rev. 2010, 14, 217-232. [CrossRef]

3. Mata, T.M.; Martins, A.A.; Caetano, N.S. Microalgae processing for biodiesel production. In Advances in Biodiesel Production: Processes and Technologies, 1st ed.; Luque, R., Melero, J.A., Eds.; Woodhead Publishing: Cambridge, UK; Elsevier Ltd.: Amsterdam, The Netherlands, 2012; pp. 204-231.

4. Mata, T.M.; Martins, A.A.; Sikdar, S.K.; Costa, C.A.V.; Caetano, N.S. Sustainability considerations about microalgae for biodiesel production. In Advanced Biofuels and Bioproducts, 1st ed.; Lee, J.W., Ed.; Springer: New York, NY, USA, 2013 ; pp. 745-757. [CrossRef] 
5. Santos, R.R.; Corrêa, P.S.; Dantas, F.M.L.; Teixeira, C.M.L.L. Evaluation of the Co-production of Total Carotenoids, C-phycocyanin and Polyhydroxyalkanoates by Arthrospira platensis. Bioresour. Technol. Rep. 2019, 7, 100226. [CrossRef]

6. Park, S.; Nguyen, T.H.T.; Jin, E. Improving Lipid Production by Strain Development in Microalgae: Strategies, Challenges and Perspectives. Bioresour. Technol. 2019, 292, 121953. [CrossRef]

7. Geresh, S.; Adin, I.; Yarmolinsky, E.; Karpasas, M. Characterization of the Extracellular Polysaccharide of Porphyridium sp.: Molecular Weight Determination and Rheological Properties. Carbohydr. Polym. 2002, 50, 183-189. [CrossRef]

8. Shrivastav, A.; Mishra, S.K.; Mishra, S. Polydroxyalkanoate (PHA) Synthesis by Spirulina subsalsa from Gujarat Coast of India. Int. J. Biol. Macromol. 2010, 46, 255-260. [CrossRef] [PubMed]

9. Chia, S.R.; Mak, K.Y.; Khaw, Y.J.; Suhaidi, N.; Chew, K.W.; Show, P.L. An efficient and rapid Method to Extract and Purify Protein-Liquid Triphasic Flotation System. Bioresour. Technol. 2019, 294, 122158. [CrossRef] [PubMed]

10. Edelmann, M.; Chamlagain, S.A.B.; Kariluoto, S.; Piironen, V. Riboflavin, Niacin, Folate and Vitamin B12 in Commercial Microalgae Powders. J. Food Compos. Anal. 2019, 82, 103226. [CrossRef]

11. Liu, L.; Pohnert, G.; Wei, D. Extracellular metabolites from industrial microalgae and their biotechnological potential. Mar. Drugs 2016, 14, 191. [CrossRef] [PubMed]

12. Chew, K.W.; Yap, J.Y.; Show, P.L.; Suan, N.H.; Juan, J.C.; Ling, T.C.; Lee, D.; Chang, J. Microalgae biorefinery: High value products perspectives. Bioresour. Technol. 2017, 229, 53-62. [CrossRef] [PubMed]

13. Alhattab, M.; Kermanshahi-Pour, A.; Brooks, M.S. Microalgae disruption techniques for product recovery: Influence of cell wall composition. J. Appl. Phycol. 2019, 31, 61-88. [CrossRef]

14. Agboola, J.O.; Teuling, E.; Wierenga, P.A.; Gruppen, H.; Schrama, J.W. Cell wall disruption: An effective strategy to improve the nutritive quality of microalgae in African catfish (Clarias gariepinus). Aquac. Nutr. 2019, 25, 783-797. [CrossRef]

15. Larrosa, A.P.Q.; Camara, A.S.; Moura, J.M.; Pinto, L.A.A. Spirulina sp. Biomass Dried/disrupted by Different Methods and their Application in Biofilms Production. Food Sci. Biotechnol. 2018, 27, 1659-1665. [CrossRef] [PubMed]

16. Gim, H.; Kim, S.W. Optimization of Cell Disruption and Transesterification of Lipids from Botryococcus braunii LB572. Biotechnol. Bioprocess Eng. 2018, 23, 550-556. [CrossRef]

17. Martínez, J.M.; Gojkovic, Z.; Ferro, L.; Maza, M.; Álvarez, I.; Raso, J.; Funk, C. Use of Pulsed Electric Field Permeabilization to Extract Astaxanthin from the Nordic Microalgae Haematococcus pluvialis. Bioresour. Technol. 2019, 289, 121694. [CrossRef]

18. Rito-Palomares, M. Bioseparation: The limiting step in bioprocess development. J. Chem. Technol. Biotechnol. 2008, 83, 115-116. [CrossRef]

19. Yu, L.; Wu, F.; Chen, G. Next-Generation Industrial Biotechnology-Transforming the Current Industrial Biotechnology into Competitive Processes. Biotechnol. J. 2019, 14, 1800437. [CrossRef]

20. Wang, M.; Chen, S.; Zhou, W.; Yuan, W.; Wang, D. Algal cell lysis by bacteria: A review and comparison to conventional methods. Algal Res. 2020, 46, 101794. [CrossRef]

21. Günerken, E.; D’Hondt, E.; Eppink, M.H.M.; Garcia-Gonzalez, L.; Elst, K.; Wijffels, R.H. Cell disruption for microalgae biorefineries. Biotech. Adv. 2015, 33, 243-260. [CrossRef]

22. Toursel, B.; Delannoy, F.; Patinier, S. Optimised Method for Breaking Chlorella Walls by Mechanical Crushing. U.S. Patent 10465159B2, 5 November 2019.

23. D’Hondt, E.D.; Martín-Juárez, J.; Kasperoviciene, J.; Koreiviene, J.; Sulcius, S.; Elst, K.; Bastiaens, L. Cell Disruption Technologies. In Microalgae-Based Biofuels and Bioproducts-From Feedstock Cultivation to End-Products; Gonzalez-Fernandez, C., Muñoz, R., Eds.; Woodhead Publishing Series in Energy: Duxford, UK, 2017; pp. 133-154. [CrossRef]

24. Balasubramanian, R.K.; Doan, T.T.Y.; Obbard, J.P. Factors affecting cellular lipid extraction from marine microalgae. Chem. Eng. J. 2013, 215-216, 929-936. [CrossRef]

25. Guedes, A.C.; Amaro, H.M.; Gião, M.S.; Malcata, F.X. Optimization of ABTS radical cation assay specifically for determination of antioxidant capacity of intracellular extracts of microalgae and cyanobacteria. Food Chem. 2013, 138, 638-643. [CrossRef]

26. González-Delgado, A.D.; Kafarov, V. Microalgae based biorefinery: Evaluation of oil extraction methods in terms of efficiency, costs, toxicity and energy in lab-scale. Rev. Ion. 2013, 26, 29-37.

27. Gomes, T.A.; Zanette, C.M.; Spier, M.R. An overview of cell disruption methods for intracellular biomolecules recovery. Prep. Biochem. Biotech. 2020, 50, 635-654. [CrossRef]

28. Bernaerts, T.M.M.; Greysen, L.; Foubert, I.; Hendrickx, M.E.; Loey, A.M.V. Evaluating microalgal cell disruption upon ultra high pressure homogenization. Algal Res. 2019, 42, 101616. [CrossRef]

29. Elain, A.; Nkounkou, C.; Fellic, M.; Donnart, K. Green extraction of polysaccharides from Arthrospira platensis using high pressure homogenization. J. Appl. Phycol. 2020, 32, 1719-1727. [CrossRef]

30. Piasecka, A.; Krzemińska, I.; Tys, J. Physical methods of microalgal biomass pretreatment. Int. Agrophys. 2014, 38, 341-348. [CrossRef]

31. Zghaibi, N.; Omar, R.; Kamal, S.M.M.; Biak, D.R.A.; Harun, R. Microwave-Assisted Brine Extraction for Enhancement of the Quantity and Quality of Lipid Production from Microalgae Nannochloropsis sp. Molecules 2019, 24, 3581. [CrossRef] [PubMed]

32. Lee, J.; Yoo, C.; Jun, S.; Ahn, C.; Oh, H. Comparison of several methods for effective lipid extraction from microalgae. Bioresour. Technol. 2010, 101, S75-S77. [CrossRef]

33. Dai, Y.; Chen, K.; Chen, C. Study of the microwave lipid extraction from microalgae for biodiesel production. Chem. Eng. J. 2014, 250, 267-273. [CrossRef] 
34. Viner, K.J.; Champagne, P.; Jessop, P.G. Comparison of cell disruption techniques prior to lipid extraction from Scenedesmus sp. slurries for biodiesel production using liquid $\mathrm{CO}_{2}$. Green Chem. 2018, 20, 4330. [CrossRef]

35. Fan, Y.; Niu, Z.; Xu, C.; Yang, L.; Chen, F.; Zhang, H. Biocompatible protic ionic liquids-based microwave-assisted liquid-solid extraction of astaxanthin from Haematococcus pluvialis. Ind. Crop. Prod. 2019, 141, 111809. [CrossRef]

36. Krishnan, S.; Ghani, N.A.; Aminuddin, N.F.; Quraishi, K.S.; Azman, N.S.; Cravotto, G.; Leveque, J. Microwave-assisted lipid extraction from Chlorella vulgaris in water with $0.5 \%-2.5 \%$ of imidazolium based ionic liquid as additive. Renew. Energ. 2020, 149, 244-252. [CrossRef]

37. Adam, F.; Abert-Vian, M.; Peltier, G.; Chemat, F. “Solvent-free” ultrasound-assisted extraction of lipids from fresh microalgae cells: A green, clean and scalable process. Bioresour. Technol. 2012, 114, 457-465. [CrossRef] [PubMed]

38. Martínez, J.M.; Delso, C.; Álvarez, I.; Raso, J. Pulsed electric field-assisted extraction of valuable compounds from microorganisms. Compr. Rev. Food Sci. Saf. 2020, 19, 530-552. [CrossRef] [PubMed]

39. Lafarga, T. Cultured microalgae and compounds derived thereof for food applications: Strain selection and cultivation, drying, and processing strategies. Food Rev. Int. 2020, 36, 559-583. [CrossRef]

40. Toepfl, S.; Heinz, V.; Knorr, D. Applications of pulsed electric fields technology for food industry. In Pulsed Electric Fields Technology for the Food Industry; Raso, J., Heinz, V., Eds.; Food Engineering Series; Springer: Boston, MA, USA, 2006; pp. 197-221. [CrossRef]

41. Arshad, R.N.; Abdul-Malek, Z.; Munir, A.; Buntat, Z.; Ahmad, M.H.; Jusoh, Y.M.M.; Bekhit, A.E.; Roobab, U.; Manzoor, M.F.; Aadil, R.M. Electrical systems for pulsed electric field applications in the food industry: An engineering perspective. Trends Food Sci. Technol. 2020, 104, 1-13. [CrossRef]

42. Lam, G.P.; Postma, P.R.; Fernandes, D.A.; Timmermans, R.A.H.; Vermuë, M.H.; Barbosa, M.J.; Eppink, M.H.M.; Wijffels, R.H.; Olivieri, G. Pulsed electric field for protein release of the microalgae Chlorella vulgaris and Neochloris oleoabundans. Algal Res. 2017, 24, 181-187. [CrossRef]

43. Käferböck, A.; Smetana, S.; Vos, R.; Schwarz, C.; Toepfl, S.; Parniakov, O. Sustainable extraction of valuable components from Spirulina assisted by pulsed electric fields technology. Algal Res. 2020, 48, 101914. [CrossRef]

44. Zhang, R.; Lebovka, N.; Marchal, L.; Vorobiev, E.; Grimi, N. Pulsed electric energy and ultrasonication assisted green solvent extraction of bio-molecules from different microalgal species. Innov. Food Sci. Emerg. Technol. 2020, 62, 102358. [CrossRef]

45. McMillan, J.R.; Watson, I.A.; Ali, M.; Jaafar, W. Evaluation and comparison of algal cell disruption methods: Microwave, waterbath, blender, ultrasonic and laser treatment. Appl. Energy 2013, 103, 128-134. [CrossRef]

46. Lorente, E.; Farriol, X.; Salvadó, J. Steam explosion as a fractionation step in biofuel production. Fuel Process Technol. 2015, 131, 93-98. [CrossRef]

47. Lorente, E.; Hapońska, M.; Clavero, E.; Torras, C.; Salvadó, J. Microalgae fractionation using steam explosion, dynamic and tangential cross-flow membrane filtration. Bioresour. Technol. 2017, 237, 3-10. [CrossRef] [PubMed]

48. Nurra, C.; Torras, C.; Clavero, E.; Ríos, S.; Rey, M.; Lorente, E.; Farriol, X.; Salvadó, J. Biorefinery concept in a microalgae pilot plant. Culturing, dynamic filtration and steam explosion fractionation. Bioresour. Technol. 2014, 163, 136-142. [CrossRef] [PubMed]

49. Al hattab, M.; Ghaly, A. Microalgae oil extraction pre-treatment methods: Critical review and comparative analysis. J. Fundam. Renew. Energy Appl. 2015, 5, 172. [CrossRef]

50. Kapoore, R.V.; Butler, T.O.; Pandhal, J.; Vaidyanathan, S. Microwave-assisted extraction for microalgae: From biofuels to biorefinery. Biology 2018, 7, 18. [CrossRef]

51. Singh, R.; Kumar, A.; Sharma, Y.C. Biodiesel Synthesis from Microalgae (Anabaena PCC 7120) by Using Barium Titanium Oxide $\left(\mathrm{Ba}_{2} \mathrm{TiO}_{4}\right)$ Solid Base Catalyst. Bioresour. Technol. 2019, 287, 121357. [CrossRef]

52. Castro, Y.A.; Ellis, J.T.; Miller, C.D.; Sims, R.C. Optimization of Wastewater Microalgae Saccharification Using Dilute Acid Hydrolysis for Acetone, Butanol, and Ethanol Fermentation. Appl. Energy 2015, 140, 14-19. [CrossRef]

53. Juárez, J.M.; Hernando, A.L.; Torre, R.M.; Lanza, S.B.; Rodríguez, S.B. Saccharification of Microalgae Biomass Obtained from Wastewater Treatment by Enzymatic Hydrolysis. Effect of Alkaline-Peroxide Pretreatment. Bioresour. Technol. 2016, 218, 265-271. [CrossRef]

54. Huang, W.; Kim, J. Cationic Surfactant-Based Method for Simultaneous Harvesting and Cell Disruption of Microalgal Biomass. Bioresour. Technol. 2013, 149, 579-581. [CrossRef]

55. Liang, K.; Zhang, Q.; Cong, W. Enzyme-Assisted Aqueous Extraction of Lipid from Microalgae. J. Agric. Food Chem. 2012, 60, 11771-11776. [CrossRef]

56. Zhang, Y.; Kong, X.; Wang, Z.; Sun, Y.; Zhu, S.; Li, L.; Lv, P. Optimization of Enzymatic Hydrolysis for Effective Lipid Extraction from Microalgae Scenedesmus sp. Renew. Energy 2018, 125, 1049-1057. [CrossRef]

57. Zhou, Y.; Lai, Y.S.; Eustance, E.; Rittmann, B.E. Promoting Synechocystis sp. PCC 6803 Harvesting by Cationic Surfactants: Alkyl-chain Length and Dose Control the Release of Extracellular Polymeric Substances and Biomass Aggregation. ACS Sustain. Chem. Eng. 2018, 7, 2127-2133. [CrossRef]

58. Lai, Y.S.; Zhou, Y.; Martarella, R.; Wang, Z.; Rittmann, B.E. Synergistic Integration of C12-C16 Cationic Surfactants for Flocculation and Lipid Extraction from Chlorella Biomass. ACS Sustain. Chem. Eng. 2017, 5, 752-757. [CrossRef]

59. Alhattab, M.; Kermanshahi-pour, A.; Brooks, S. Dispersed Air Flotation of Chlorella saccharophila and subsequent Extraction of Lipids-Effect of Supercritical $\mathrm{CO}_{2}$ Extraction Parameters as Surfactant Pretreatment. Biomass Bioenerg. 2019, $127,105297$. [CrossRef] 
60. Rakesh, S.; Dhar, D.W.; Prasanna, R.; Saxena, A.K.; Saha, S.; Shukla, M.; Sharma, K. Cell disruption methods for improving lipid extraction efficiency in unicellular microalgae. Eng. Life Sci. 2015, 15, 443-447. [CrossRef]

61. González-González, L.M.; Astals, S.; Pratt, S.; Jensen, P.D.; Schenk, P.M. Impact of osmotic shock pre-treatment on microalgae lipid extraction and subsequent methane production. Bioresour. Technol. Rep. 2019, 7, 100214. [CrossRef]

62. López, B.H.; Morales, J.M.V. Extraction of antioxidants from Haematococcus pluvialis by osmotic shock with sucrose, for use in the preparation of syrup for jams. In Proceedings of the XIV International Engineering Congress (CONIIN), Queretaro, Mexico, 14-19 May 2018; pp. 1-5. [CrossRef]

63. Koyande, A.K.; Tanzil, V.; Dharan, H.M.; Subramaniam, M.; Robert, R.N.; Lau, P.; Khoiroh, I.; Show, P. Integration of osmotic shock assisted liquid biphasic system for protein extraction from microalgae Chlorella vulgaris. Biochem. Eng. J. 2020, 157, 107532 [CrossRef]

64. Heo, Y.M.; Lee, H.; Lee, C.; Kang, J.; Ahn, J.; Lee, Y.M.; Kang, K.; Choi, Y.; Kim, J. An integrative process for obtaining lipids and glucose from Chlorella vulgaris biomass with a single treatment of cell disruption. Algal Res. 2017, 27, 286-294. [CrossRef]

65. Mercer, P.; Armenta, R.E. Developments in oil extraction from microalgae. Eur. J. Lipid Sci. Technol. 2011, 113, 539-547. [CrossRef]

66. Zheng, Y.; Xiao, R.; Roberts, M. Polymer-enhanced enzymatic microalgal cell disruption for lipid and sugar recovery. Algal Res. 2016, 14, 100-108. [CrossRef]

67. Bai, M.; Han, C.; Lu, W.; Wan, H.; Chang, J.; Chen, C.; Chang, H. Method for Manufacturing an Active Substance for Inducing Self-Lysis in Microalga Cells, Active Substance Obtained Therefrom, and Method for Inducing Self-Lysis in Microalga Cells. U.S Patent 10196600B2, 5 February 2019.

68. Chia, S.R.; Chew, K.W.; Show, P.L.; Xia, A.; Ho, S.; Lim, J.W. Spirulina platensis based biorefinery for the production of value-added products for food and pharmaceutical applications. Bioresour. Technol. 2019, 289, 121727. [CrossRef] [PubMed]

69. Van Eykelenburg, C. Spirulina platensis: Morphology and Ultrastructure. Ph.D. Thesis, Delft University, Delft, The Netherlands, 1980. Available online: https:/ / repository.tudelft.nl/islandora/object/uuid\%3A744c0474-507a-42c7-b29b-4139f7cb4f22 (accessed on 20 September 2020).

70. Gouveia, J.D.G. The Effects of Light Quality on the Morphology and Hydrocarbon Production of Botryococcus braunii. Master's Thesis, University of Exeter, Exeter, UK, September 2010. Available online: https://core.ac.uk/download/pdf/12826395.pdf (accessed on 20 September 2020).

71. Wang, S.; Hu, Q.; Sommerfeld, M.; Chen, F. Cell wall proteomics of the green alga Haematococcus pluvialis (Chlorophyceae). Proteomics 2004, 4, 692-708. [CrossRef] [PubMed]

72. Yuan, T.; Li, X.; Xiao, S.; Guo, Y.; Zhou, W.; Xu, J.; Yuan, Z. Microalgae Pretreatment with Liquid Hot Water to Enhance Enzymatic Hydrolysis Efficiency. Bioresour. Technol. 2016, 220, 530-536. [CrossRef] [PubMed]

73. Zhou, J.; Zhang, F.; Meng, H.; Bao, G.; Zhang, Y.; Li, Y. Development of a Silicon Carbide Disruption Method Enables Efficient Extraction of Proteins from Cyanobacterium Synechocystis sp. PCC 6803. Process Biochem. 2014, 49, 2199-2202. [CrossRef]

74. Woitzik, D.; Weckesser, J.; Jürgens, U. Isolation and characterization of cell wall components of the unicellular cyanobacterium Synechococcus sp. PCC 6307. J. Gen. Microbiol. 1988, 134, 619-627. [CrossRef]

75. Gille, A.; Hollenbach, R.; Trautmann, A.; Posten, C.; Brivida, K. Effect of Sonication on Bioaccessibility and Cellular Uptake of Carotenoids from Preparations of Photoautotrophic Phaeodactylum tricornutum. Food Res. Int. 2019, 118, 40-48. [CrossRef]

76. Serive, B.; Kaas, R.; Bérard, J.; Pasquet, V.; Picot, L.; Cadoret, J. Selection and Optimisation of a Method for Efficient Metabolites Extraction from Microalgae. Bioresour. Technol. 2012, 124, 311-320. [CrossRef]

77. De Martino, A.; Meichenin, A.; Shi, J.; Pan, K.; Bowler, C. Genetic and Phenotypic Characterization of Phaeodactylum tricornutum (Bacillariophyceae) Accessions. J. Phycol. 2007, 43, 992-1009. [CrossRef]

78. Ramos, G.J.P.; Bicudo, C.E.M.; Neto, A.G.; Moura, C.W.N. Monoraphidium and Ankistrodesmus (Chlorophyceae, Chlorophyta) from Pantanal dos Marimbus, Chapada Diamantina, Bahia State, Brazil. Hoehnea 2012, 39, 421-434. [CrossRef]

79. Imam, S.H.; Snell, W.J. The Chlamydomonas cell wall degrading enzyme, lysine, acts on two substrates within the framework of the wall. J. Cell Biol. 1988, 106, 2211-2221. [CrossRef]

80. Wilson, D.P. The triradiate and other forms of Nitzschia closterium (Ehrenberg) Wm. Smith, forma minutissima of Allen and Nelson. J. Mar. Biol. Assoc. UK 1946, 26, 235-270. [CrossRef]

81. Patel, A.; Mikes, F.; Matsakas, L. An overview of current pretreatment methods used to improve lipid extraction from oleaginous microorganisms. Molecules 2018, 23, 1562. [CrossRef] [PubMed]

82. Pora, B.; Qian, Y.; Caulier, B.; Comini, S.; Looten, P.; Segueilha, L. Method for the Preparation and Extraction of Squalene from Microalgae. U.S. Patent 10087467B2, 2 October 2018.

83. Zanella, L.; Pertile, P.; Massironi, M.; Massironi, M.; Caviola, E. Extracts of Microalgae and their Applications. U.S. Patent 9974819B2, 22 May 2018.

84. Massetti, F.; Capuano, F.; Medici, R.; Miglio, R. Process for the Extraction of Lipids and Sugars from Algal Biomass. U.S. Patent 10336965B2, 2 July 2019.

85. Reddy, C.M.; O'Neil, G.W. Use of Marine Algae for co-Producing Alkenones, Alkenone Derivatives and Co-Products. U.S. Patent 10208321B2, 19 February 2019.

86. Nakazawa, A.; Matsuura, H.; Kose, R.; Kato, S.; Honda, D.; Inouye, I.; Kaya, K.; Watanabe, M. Optimization of culture conditions of the thraustochytrid Aurantiochytrium sp. strain 18W-13a for squalene production. Bioresour. Technol. 2012, 109, 287-291. [CrossRef] [PubMed] 
87. Kaya, K.; Nakazawa, A.; Matsuura, H.; Honda, D.; Inouye, I.; Watanabe, M. Thraustochytrid Aurantiochytrium sp. 18W-13a accumulates high amounts of squalene. Biosci. Biotechnol. Biochem. 2011, 75, 2246-2248. [CrossRef] [PubMed]

88. Hoang, M.H.; Ha, N.C.; Thom, L.T.; Tam, L.T.; Anh, H.T.L.; Thu, N.T.H.; Hong, D.D. Extraction of squalene as value-added product from the residual biomass of Schizochytrium mangrovei PQ6 during biodiesel producing process. J. Biosci. Bioeng. 2014, 118, 632-639. [CrossRef]

89. Patel, A.; Liefeldt, S.; Rova, U.; Christakopoulos, P.; Matsakas, L. Co-production of DHA and squalene by Thraustochytrid from forest biomass. Sci. Rep. 2020, 10, 1992. [CrossRef]

90. Li, Q.; Chen, G.; Fan, K.; Lu, F.; Aki, T.; Jiang, Y. Screening and Characterization of Squalene-producing Thraustochytrids from Hong Kong Mangroves. J. Agric. Food Chem. 2009, 57, 4267-4272. [CrossRef]

91. Du, Y.; Schuur, B.; Brilman, D.W.F. Maximizing lipid yield in Neochloris oleoabundans algae extraction by stressing and using multiple extraction stages with n-ethlylbutylamine as switchable solvent. Ind. Eng. Chem. Res. 2017, 56, 8073-8080. [CrossRef]

92. Obeid, S.; Beaufils, N.; Camy, S.; Takache, H.; Ismail, A.; Pontalier, P. Supercritical carbon dioxide extraction and fractionation of lipids from freeze-dried microalgae Nannochloropsis oculata and Chlorella vulgaris. Algal Res. 2019, 34, 49-56. [CrossRef]

93. Hernández, D.; Solana, M.; Riaño, B.; García-González, M.C.; Bertucco, A. Biofuels from microalgae: Lipid extraction and methane production from residual biomass in a biorefinery approach. Bioresour. Technol. 2014, 170, 370-378. [CrossRef]

94. Leone, G.P.; Balducchi, R.; Mehariya, S.; Martino, M.; Larocca, V.; Di Sanzo, G.; Lovine, A.; Casella, P.; Marino, T.; Karatza, D.; et al. Selective Extraction of $\omega-3$ Fatty Acids from Nanochloropsis sp. Using Supercritical $\mathrm{CO}_{2}$ Extraction. Molecules 2019, $24,2406$. [CrossRef] [PubMed]

95. Bligh, E.G.; Dyer, W.J. A rapid method of total lipid extraction and purification. Can. J. Biochem. Physiol. 1959, 37, 911-917. [CrossRef] [PubMed]

96. Folch, J.; Lees, M.; Stanley, G.H.S. A simple method for the isolation and purification of total lipids from animal tissues. J. Biol. Chem. 1956, 226, 497-509.

97. Kumar, R.R.; Rao, P.H.; Arumugan, M. Lipid extraction methods from microalgae: A comprehensive review. Front. Energy Res. 2015, 2, 1-9. [CrossRef]

98. Guldhe, A.; Singh, B.; Ansari, F.A.; Sharma, Y.; Bux, F. Extraction and conversion of microalgal lipids. In Algae Biotechnology; Bux, F., Chisti, Y., Eds.; Green Energy and Technology; Springer: New York, NY, USA, 2016; pp. 91-110. [CrossRef]

99. Breil, C.; Vian, M.A.; Zemb, T.; Kunz, W.; Chemat, F. "Bligh and Dyer" and Folch methods for solid-liquid-liquid extraction of lipids from microorganisms. Comprehension of solvatation mechanisms and towards substitution with alternatives solvents. Int. J. Mol. Sci. 2017, 18, 708. [CrossRef] [PubMed]

100. Gorgich, M.; Mata, T.M.; Martins, A.A.; Branco-Vieira, M.; Caetano, N.S. Comparison of different lipid extraction procedures applied to three microalgal species. Energy Rep. 2020, 6, 477-482. [CrossRef]

101. Ruecker, C.M.; Adu-Peasah, S.P.; Engelhardt, B.S.; Veeder, G.T. Soventless Extraction Process. U.S. Patent 10329515B2, 25 June 2019.

102. Doble, M.; Kruthiventi, A.M. Alternate solvents. In Green Chemistry and Engineering; Doble, M., Kruthiventi, A.M., Eds.; Academic Press: New York, NY, USA, 2007; pp. 93-104. [CrossRef]

103. Clarke, C.J.; Tu, W.; Levers, O.; Bröhl, A.; Hallett, J.P. Green and sustainable solvents in chemical processes. Chem. Rev. 2018, 118, 747-800. [CrossRef]

104. Bubalo, M.C.; Radoševic, K.; Redovniković, I.R.; Halambek, J.; Srček, V.G. A brief overview of the potential environmental hazards of ionic liquids. Ecotox Environ. Saf. 2014, 99, 1-12. [CrossRef]

105. Ho, T.D.; Zhang, C.; Hantao, L.W.; Anderson, J.L. Ionic Liquids in Analytical Chemistry: Fundamentals, Advances, and Perspectives. Anal. Chem. 2014, 86, 262-285. [CrossRef]

106. Zhou, W.; Wang, Z.; Alam, M.A.; Xu, J.; Zhu, S.; Yuan, Z.; Huo, S.; Guo, Y.; Qin, L.; Ma, L. Repeated utilization of ionic liquid to extract lipid from algal biomass. Int. J. Polym. Sci. 2019, 9209210, 1-7. [CrossRef]

107. To, T.Q.; Procter, K.; Simmons, B.A.; Subasshchandrabose, S.; Atkin, R. Low cost ionic liquid-water mixtures for effective extraction of carbohydrate and lipid from algae. Faraday Discuss 2018, 206, 93. [CrossRef] [PubMed]

108. Yu, Z.; Chen, X.; Xia, S. The mechanism of lipids extraction from wet microalgae Scenedesmus sp. by ionic liquid assisted subcritical water. J. Ocean Univ. China 2016, 15, 549-552. [CrossRef]

109. El Archkar, T.; Fourmentin, S.; Greige-Gerges, H. Deep eutectic solvents: An overview on their interactions with water and biochemical compounds. J. Mol. Liq. 2019, 288, 111028. [CrossRef]

110. Lu, W.; Alam, M.A.; Pan, Y.; Wu, J.; Wang, Z.; Yuan, Z. A new approach of microalgal biomass pretreatment using deep eutectic solvents for enhance lipid recovery for biodiesel production. Bioresour. Technol. 2016, 218, 123-128. [CrossRef]

111. Jablonský, M.; Škulcová, A.; Šima, J. Use of deep eutectic solvents in polymer chemisty-A review. Molecules 2019, $24,3978$. [CrossRef]

112. Mahmood, W.M.A.W.; Lorwirachsutee, A.; Theodoropoulos, C.; Conzalez-Miguel, M. Polyol-based deep eutectic solvents for extraction of natural polyphenolic antioxidants from Chlorella vulgaris. ACS Sustain. Chem. Eng. 2019, 7, 5018-5026. [CrossRef]

113. Pan, Y.; Alam, M.A.; Wang, Z.; Huang, D.; Hu, K.; Chen, H.; Yuan, Z. One-step production of biodiesel from wet and unbroken microalgae biomass using deep eutectic solvent. Bioresour. Technol. 2017, 238, 157-163. [CrossRef]

114. Manjare, S.D.; Dhingra, K. Supercritical Fluids in Separation and Purification: A Review. Mater Sci. Energy Technol. 2019, 2, 463-484. [CrossRef] 
115. Johner, J.C.F.; Meireles, M.A.A. Construction of a Supercritical Fluid Extraction (SFE) Equipment: Validation Using Annato and Fennel and Extract Analysis by Thin Layer Chromatography Couple to Image. Food Sci. Technol. 2016, 36, 210-247. [CrossRef]

116. Knez, Ž.; Pantić, M.; Cör, D.; Novak, Z.; Hrnčič, M.K. Are Supercritical Fluids Solvents for the Future? Chem. Eng. Process 2019, 141, 107532. [CrossRef]

117. Yang, X.; Li, Y.; Li, Y.; Ye, D.; Yuan, L.; Sun, Y.; Han, D.; Hu, Q. Solid Matrix-Supported Supercritical CO 2 Enhances Extraction of $\gamma$-Linolenic Acid from Cyanobacterium Arthrospira (Spirulina) platensis and Bioactivity Evaluation of the Molecule in Zebrafish. Mar. Drugs 2019, 17, 203. [CrossRef] [PubMed]

118. Feller, R.; Matos, A.P.; Mazzutti, S.; Moecke, E.H.S.; Tres, M.V.; Derner, R.B.; Oliveira, J.V.; Junior, A.F. Polyunsaturated $\omega-3$ and $\omega-6$ Fatty Acids, Total Carotenoids and Antioxidant Activity of Three Marine Microalgae Extracts Obtained by Supercritical $\mathrm{CO}_{2}$ and Subcritical n-butane. J. Supercrit. Fluids 2018, 133, 437-443. [CrossRef]

119. Chronopoulou, L.; Dal Bosco, C.; Di Caprio, F.; Prosini, L.; Gentili, A.; Pagnanelli, F.; Palocci, C. Extraction of Carotenoids and Fat-Soluble Vitamins from Tetradesmus obliquus Microalgae: An Optimized Approach by Using Supercritical $\mathrm{CO}_{2}$. Molecules 2019, 24, 2581. [CrossRef]

120. Mendiola, J.A.; García-Martínez, D.; Rupérez, F.J.; Martínez-Álvarez, P.J.; Reglero, G.; Cifuentes, A.; Barbas, C.; Ibañez, E.; Señoráns, F.J. Enrichment of Vitamin E from Spirulina platensis Microalga by SFE. J. Supercrit. Fluids 2008, 43, 484-489. [CrossRef]

121. Mendiola, J.A.; Marín, F.R.; Hernández, S.F.; Arredondo, B.O.; Señoráns, F.J.; Ibañez, E.; Reglero, G. Characterization via Liquid Chromatography Coupled to Diode Array Detector and Tandem Mass Spectrometry of Supercritical Fluid Antioxidant Extracts of Spirulina platensis Microalga. J. Sep. Sci. 2005, 28, 1031-1038. [CrossRef]

122. Mehariya, S.; Lovine, A.; Di Sanzo, G.; Larocca, V.; Martino, M.; Leone, G.P.; Casella, P.; Karatza, D.; Marino, T.; Musmarra, D.; et al. Supercritical Fluid Extraction of Lutein from Scenedesmus almeriensis. Molecules 2019, 24, 1324. [CrossRef]

123. Molino, A.; Martino, M.; Larocca, V.; Di Sanzo, G.; Spagnoletta, A.; Marino, T.; Karatza, D.; Lovine, A.; Mehariya, S. Eicosapentaenoic Acid Extraction from Nannochloropsis gaditana Using Carbon Dioxide at Supercritical Conditions. Mar. Drugs 2019, 17, 132. [CrossRef]

124. Ferreira, A.F.; Ribeiro, L.A.; Batista, A.P.; Marques, P.A.S.S.; Nobre, B.P.; Palavra, A.M.F.; Silva, P.P.; Gouveia, L.; Silva, C. A biorefinery from Nannochloropsis sp. microalga-Energy and $\mathrm{CO}_{2}$ emission and economic analyses. Bioresour. Technol. 2013, 138, 235-244. [CrossRef]

125. Coskun, O. Separation Techniques: Chromatography. North Clin. Istanbul. 2016, 3, 156-160. [CrossRef]

126. Rajan, P.M.V.; Barron, A.R. Physical Methods in Chemistry and Nano Science. Openstax CNX ${ }^{\mathrm{TM}}$, 337-392. Available online: http:/ / cnx.org/content/col10699/1.25/ (accessed on 25 September 2019).

127. Abrahamsson, V.; Rodriguez-Meizoso, I.; Turner, C. Determination of Carotenoids in Microalgae Using Supercritical Fluid Extraction and Chromatography. J. Chromatogr. A 2012, 1250, 63-68. [CrossRef]

128. Aluç, Y.; Kankilic, G.B.; Tüzün, I. Determination of Carotenoids in Two Algae Species from the Saline Water of Kapulukaya Reservoir by HPLC. J. Liq. Chromatogr. R. T 2018, 41, 93-100. [CrossRef]

129. Ahuja, S. Chromatographic methods. In Chromatography and Separation Science; Academic Press: New York, NY, USA, 2003; pp. 81-100.

130. Nawrocki, J. Silica Surface Controversies, Strong Adsorption Sites, their Blockage and Removal. Part I. J. Chromatogr. 1991, 31, 177. [CrossRef]

131. Nawrocki, J. Silica Surface Controversies, Strong Adsorption Sites, their Blockage and Removal. Part II. J. Chromatogr. 1991, 31, 193. [CrossRef]

132. Claessens, H.A.; van Straten, M.A. Review on the Chemical and Thermal Stability of Stationary Phases for Reversed-Phase Liquid Chromatography. J. Chromatogr. A 2004, 1060, 23-41. [CrossRef]

133. Venegas-Venegas, E.; Guil-Guerrero, J.L.; Rincón-Cervera, M.A.; Ramos-Bueno, R.P. Tricosahexaenoyl glycerol Purification from Docosahexanoic Acid Single Cell Oil (DHASCO). Eur. J. Lipid Sci. Technol. 2014, 116, 266-271. [CrossRef]

134. González-Fernández, M.J.; Ramos-Bueno, R.P.; Rodríguez-García, I.; Guil-Guerrero, J.L. Purification Process for MUFA- and PUFA- based Monoacylglycerols from Edible Oils. Biochimie 2017, 139, 107-114. [CrossRef]

135. Ronda, S.R.; Lele, S. Argentated Silica Gel Chromatography for Separation of $\gamma$-linolenic Acid from Microalgae. Biosci. Biotech. Res. Asia 2007, 4, 621-626.

136. Guil-Guerrero, J.L.; Belarbi, E.; Rebolloso-Fuentes, M.M. Eicosapentaenoic and arachidonic acids purification from the red microalga Porphyridium cruentum. Bioseparation 2001, 9, 299-306. [CrossRef]

137. Wu, H.; Fu, X.; Cao, W.; Xiang, W.; Hou, Y.; Ma, J.; Wang, Y.; Fan, C. Induction of Apoptosis in Human Glioma Cells by Fucoxanthin via Triggering of ROS-Mediated Oxidative Damage and Regulation of MAPKs and PI3K-AKT Pathways. J. Agric. Food Chem. 2019, 67, 2212-2219. [CrossRef]

138. Schröder, E.; Jönsson, T.; Poole, L. Hydroxyapatite chromatography: Altering the phosphate-dependent elution profile of protein as a function of pH. Anal. Biochem. 2003, 313, 176-178. [CrossRef]

139. Reuter, W.; Nickel, C.; Wehmeyer, W. Isolation of Allophycocyanin B from Rhodella violacea Results in a Model of the Core from Hemidiscoidal Phycobilisomes of Rhodophyceae. FEBS Lett. 1990, 273, 155-158. [CrossRef]

140. Gómez-Lojero, C.; Pérez-Gómez, B.; Krogmann, D.W.; Peña-Diaz, A. The Tricylindrical Core of the Phycobilisome of the Cyanobacterium Arthrospira (Spirulina) maxima. Int. J. Biochem. Cell Bid. 1997, 29, 959-970. [CrossRef] 
141. Rossano, R.; Ungaro, N.; D’Ambrosio, A.; Liuzzi, G.M.; Riccio, P. Extracting and Purifying R-phycoerythrin from Mediterranean Red Algae Corallina elongata Ellis \& Solander. J. Biotechnol. 2002, 101, 289-293. [CrossRef]

142. Niu, J.; Wang, G.; Lin, X.; Zhou, B. Large-scale recovery of C-phycocyanin from Spirulina platensis using expanded bed adsorption chromatography. J. Chromatogr. B 2006, 850, 267-276. [CrossRef] [PubMed]

143. Yang, F.; Wong, K.; Yang, Y.; Li, X.; Jiang, J.; Zheng, W.; Wu, H.; Chen, T. Purification and in vitro antioxidant activities of tellurium-containing phycobiliproteins from tellurium-enriched Spirulina platensis. Drug Des. Dev. Ther. 2014, 8, 1789-1800. [CrossRef]

144. Cai, C.; Wu, L.; Li, C.; He, P.; Li, J.; Zhou, J. Purification, Crystallization and Preliminary X-ray Analysis of Phycocyanin and Phycoerythrin from Porphyra yezoensis Ueda. Acta Cryst. 2011, F67, 579-583. [CrossRef]

145. Ohsawa, N.; Tsujita, M.; Morikawa, S.; Itoh, N. Purification and Characterization of a Monohalomethane-producing Enzyme S-adenosyl-L-methionine: Halide Ion Methyltransferase from a Marine Microalga, Pavlova pinguis. Biosci. Biotechnol. Biochem. 2001, 65, 2397-2404. [CrossRef]

146. Ravi, A.; Guo, S.; Rasala, B.; Tran, M.; Mayfield, S.; Nikolov, Z.L. Separation Options for Phosphorylated Osteopontin from Transgenic Microalgae Chlamydomonas reinhardtii. Int. J. Mol. Sci. 2018, 19, 585. [CrossRef]

147. Williams, T. Gel Permeation Chromatography: A Review. J. Mater. Sci. 1970, 5, 811-820. [CrossRef]

148. Zhang, J.; Liu, L.; Ren, Y.; Chen, F. Characterization of Exopolysaccharides Produced by Microalgae with Antitumor Activity on Human Colon Cancer Cells. Int. J. Biol. Macromol. 2019, 128, 761-767. [CrossRef]

149. Yang, X.; Liu, M.; Qi, B.; Li, L.; Deng, J.; Hu, X.; Wu, Y.; Hao, S. Extraction, Purification and Partial Characterizations of Polysaccharides from Gracilaria lemaneiformis. Adv. Mat. Res. 2014, 881-883, 776-780. [CrossRef]

150. Muhamad, I.I.; Zulkifli, N.; Selvakumaran, S.; Lazim, N.A.M. Bioactive Algal-Derived Polysaccharides: Multi-Functionalization, Therapeutic Potential and Biomedical Applications. Curr. Pharm. Des. 2019, 25, 1147-1162. [CrossRef] [PubMed]

151. de Morais, M.G.; Stillings, C.; Dersch, R.; Rudisile, M.; Pranke, P.; Costa, J.A.V.; Wendorff, J. Extraction of Poly(3-hydroxybutyrate) from Spirulina LEB 18 for Developing Nanofibers. Polimeros 2015, 25, 161-167. [CrossRef]

152. GE Healthcare. Ion Exchange Chromatography \& Chromatofocusing. Principles and Methods. 2010. Available online: https://www.gelifesciences.com/en/us/solutions/protein-research/knowledge-center/protein-purification-methods/ionexchange-chromatography (accessed on 25 September 2019).

153. Owczarek, B.; Gerszberg, A.; Hnatuszko-Konka, K. A Brief Reminder of Systems of Production and Chromatography-Based Recovery of Recombinant Protein Biopharmaceuticals. BioMed. Res. Int. 2019, 1-13. [CrossRef]

154. Chen, K.; Wang, S.S.; Show, P.; Hsu, S.; Chang, Y. Rapid and Efficient Recovery of C-Phycocyanin from Highly Turbid Spirulina platensis Algae Using Stirred Fluidized Bed Ion Exchange Chromatography. Sep. Purif. Technol. 2019, 209, 636-645. [CrossRef]

155. Tang, Z.; Zhao, J.; Ju, B.; Li, W.; Wen, S.; Pu, Y.; Qin, S. One-step chromatographic procedure for purification of B-phycoerythrin from Porphyridium cruentum. Protein Expr. Purif. 2016, 123, 70-74. [CrossRef]

156. Urh, M.; Simpson, D.; Zhao, K. Affinity Chromatography: General Methods. Methods Enzymol. 2009, 463, 417-438. [CrossRef]

157. Mangold, H.K. Dietary Fats and Health; Perkins, E.G., Visek, W.J., Eds.; American Oil Chemists' Society: Champaign, IL, USA, 1983; pp. 110-123.

158. Yang, M.; Meng, Y.; Chu, Y.; Fan, Y.; Cao, X.; Xue, S.; Chi, Z. Triacylglycerol accumulates exclusively outside the chloroplast in shortterm nitrogen-deprived Chlamydomonas reinhardtii. BBA-Mol. Cell Biol. Lipids 2018, 1863, 1478-1487. [CrossRef]

159. Shen, P.; Wang, H.; Pan, Y.; Meng, Y.; Wu, P.; Xue, S. Identification of Characteristic Fatty Acids to Quantify Triacylglycerols in Microalgae. Front. Plant. Sci. 2016, 7, 162. [CrossRef]

160. Dyńska-Kukulska, K.; Ciesielski, W. Methods of extraction and thin-layer chromatography determination of phospholipids in biological samples. Rev. Anal. Chem. 2012, 31, 43-56. [CrossRef]

161. Lage, S.; Gentili, F.G. Quantification and Characterisation of Fatty Acid Methyl Esters in Microalgae: Comparison of Pretreatment and Purification Methods. Bioresour. Technol. 2018, 257, 121-128. [CrossRef] [PubMed]

162. Sun, P.; Wong, C.; Li, Y.; He, Y.; Mao, X.; Wu, T.; Ren, Y.; Chen, F. A Novel Strategy for Isolation and Purification of Fucoxanthinol and Fucoxanthin from the Diatom Nitzschia laevis. Food Chem. 2019, 277, 566-572. [CrossRef] [PubMed]

163. Żyszka-Haberecht, B.; Poliwoda, A.; Lipok, J. Structural constraints in cyanobacteria-mediated whole-cell biotransformation of methoxylated and methylated derivatives of 2'-hydroxychalcone. J. Biotechnol. 2019, 293, 36-46. [CrossRef] [PubMed]

164. Jaime, L.; Mendiola, J.A.; Herrero, M.; Soler-Rivas, C.; Santoyo, S.; Señorans, F.J.; Cifuentes, A.; Ibáñez, E. Separation and characterization of antioxidants from Spirulina platensis microalga combining pressurized liquid extraction, TLC, and HPLC-DAD. J. Sep. Sci. 2005, 28, 2111-2119. [CrossRef]

165. de Jesus, S.S.; Ferreira, G.F.; Maciel, M.R.W.; Filho, R.M. Biodiesel Purification by Column Chromatography and Liquid-Liquid Extraction Using Green Solvents. Fuel 2019, 235, 1123-1130. [CrossRef]

166. Harris, D.C. Quantitative Chemical Analysis, 8th ed.; W. H. Freeman and Company: New York, NY, USA, 2007.

167. Cerón-Garcia, M.C.; González-López, C.V.; Camacho-Rodríguez, J.; López-Rosales, L.; García-Camacho, F.; Molina-Grima, E. Maximizing Carotenoid Extraction from Microalgae Used as Food Additives and Determined by Liquid Chromatography (HPLC). Food Chem. 2018, 257, 316-324. [CrossRef]

168. Soares, A.T.; Júnior, J.G.M.; Lopes, R.G.; Derner, R.B.; Filho, N.R.A. Improvement of the Extraction Process for High Commercial Value Pigments from Desmodesmus sp. Microalgae. J. Braz. Chem. Soc. 2016, 27, 1083-1093. [CrossRef] 
169. Morowvat, M.H.; Ghasemi, Y. Developing a Robust Method for Quantification of $\beta$-Carotene in Dunaliella salina Biomass Using HPLC Method. Int. J. Pharm. Clin. Res. 2016, 8, 1423-1428.

170. Soares, A.T.; da Costa, D.C.; Vieira, A.A.H.; Filho, N.R.A. Analysis of Major Fatty Acid Composition of Freshwater Microalgae. Heliyon 2019, 5, e01529. [CrossRef]

171. Jones, J.; Manning, S.; Montoya, M.; Keller, K.; Poenie, M. Extraction of Algal Lipids and Their Analysis by HPLC and Mass Spectrometry. J. Am. Oil Chem. Soc. 2012, 89, 1371-1381. [CrossRef]

172. Jerez-Martel, I.; García-Poza, S.; Rodríguez-Martel, G.; Rico, M.; Afonso-Olivares, C.; Gómez-Pinchetti, J.L. Phenolic Profile and Antioxidant Activity of Crude Extracts from Microalgae and Cyanobacteria Strains. J. Food Qual. 2017, 1-8. [CrossRef]

173. Hussain, A.; AlAjmi, M.F.; Hussain, I.; Ali, I. Future of Ionic Liquids for Chiral Separations in High-Performance Liquid Chromatography and Capillary Electrophoresis. Crit. Rev. Anal. Chem. 2019, 49, 289-305. [CrossRef] [PubMed]

174. Ventura, S.P.M.; Nobre, B.P.; Ertekin, F.; Hayes, M.; Garciá-Vaquero, M.; Vieira, F.; Koc, M.; Gouveia, L.; Aires-Barros, M.R.; Palavra, A.M.F. Extraction of Value-Added Compounds from Microalgae. In Microalgae-Based Biofuels and Bioproducts; Gonzalez-Fernandez, C., Muñoz, R., Eds.; Woodhead Publishing: Cambridge, UK, 2017. [CrossRef]

175. Berthod, A.; Ruiz-Angel, M.; Hassoun, M. Countercurrent Chromatography. Extrus. Elution 2007, 1-8. [CrossRef]

176. Fábryová, T.; Cheel, J.; Kubáč, D.; Hrouzek, P.; Vu, D.L.; Tůmová, L.; Kopecký, J. Purification of Lutein from the Green Microalgae Chlorella vulgaris by Integrated use a New Extraction Protocol and a Multi-injection High Performance CounterCurrent Chromatography (HPCCC). Algal Res. 2019, 41, 101574. [CrossRef]

177. Cheel, J.; Kučerová, P.; Garrard, I.; Ignatova, S.; Hrouzek, P.; Kopecký, J. Two-Step Separation of Nostotrebin 6 from Cultivated Soil Cyanobacterium (Nostoc sp.) by High Performance Countercurrent Chromatography. Molecules 2014, 19, 8773-8787. [CrossRef] [PubMed]

178. Khan, B.M.; Liu, Y. High Speed Counter Current Chromatography: Overview of Solvent-system and Elution-mode. J. Liq. Chromatogr. Relat. Technol. 2018, 41, 629-636. [CrossRef]

179. Li, H.; Chen, F. Separation and Purification of Epimedin A, B, C, and Icariin from the Medicinal Herb Epimedium brevicornum Maxim by Dual-Mode HSCCC. J. Chromatogr. Sci. 2009, 47, 337-340. [CrossRef]

180. Wu, X.; Li, R.; Zhao, Y.; Liu, Y. Separation of Polysaccharides from Spirulina platensis by HSCCC with Ethanol-Ammonium Sulfate ATPS and Their Antioxidant Activities. Carbohydr. Polym. 2017, 173, 465-472. [CrossRef]

181. Lu, H.; Jiang, Y.; Chen, F. Preparative Separation and Purification of Squalene from the Microalga Thraustochytrium ATCC 26185 by High-Speed Counter-Current Chromatography. J. Chromatogr. A 2003, 994, 37-43. [CrossRef]

182. Chen, F.; Li, H.; Wong, R.N.; Ji, B.; Jiang, Y. Isolation and Purification of the Bioactive Carotenoid Zeaxanthin from the Microalga Microcystis aeruginosa by High-Speed Counter-Current Chromatography. J. Chromatogr. A 2005, 1064, 183-186. [CrossRef]

183. Li, H.; Fan, K.; Chen, F. Isolation and Purification of Canthaxanthin from the Microalga Chlorella zofingiensis by High-Speed Counter-Current Chromatography. J. Sep. Sci. 2006, 29, 699-703. [CrossRef] [PubMed]

184. Cheel, J.; Urajová, P.; Hájek, J.; Hrouzek, P.; Kuzma, M.; Bouju, E.; Faure, K.; Kopecký, J. Separation of Cyclic Lipopeptide Puwainaphycins from Cyanobacteria by Countercurrent Chromatography Combined with Polymeric Resins and HPLC. Anal. Bioanal. Chem. 2017, 409, 917-930. [CrossRef] [PubMed]

185. Rose, B.A. Gas Chromatography and its Analytical Applications. A Review. Analyst 1959, 84, 574b-595. [CrossRef]

186. Biedermann, M.; Grob, K. Advantages of Comprehensive Two-Dimensional Gas Chromatography for Comprehensive Analysis of Potential Migrants from Food Contact Materials. Anal. Chim. Acta 2019, 1057, 11-17. [CrossRef] [PubMed]

187. Lebanov, L.; Tedone, L.; Kaykhaii, M.; Linford, M.R.; Paull, B. Multidimensional Gas Chromatography in Essential Oil Analysis. Part 1: Technical Developments. Chromatographia 2019, 82, 377-398. [CrossRef]

188. Kusch, P. Application of Pyrolysis-Gas Chromatography/Mass Spectrometry (Py-GC/MS). Compr. Anal. Chem. 2017, 75, 169-207. [CrossRef]

189. Liu, C.; Duan, X.; Chen, Q.; Chao, C.; Lu, Z.; Lai, Q.; Megharaj, M. Investigations on Pyrolysis of Microalgae Diplosphaera sp. MM1 by TG-FTIR and Py-GC/MS: Products and Kinetics. Bioresour. Technol. 2019, 294, 122126. [CrossRef] [PubMed]

190. Berg, J.M.; Tymoczko, J.L.; Stryer, L. The Purification of Proteins Is an Essential First Step in Understanding Their Function. In Biochemistry, 5th ed.; W. H. Freeman and Company: New York, NY, USA, 2002. Available online: https://www.ncbi.nlm.nih.gov/ books /NBK22410 (accessed on 25 September 2019).

191. Smith, R. Two-Dimensional Electrophoresis: An Overview. In Methods in Molecular Biology, Two-Dimensional Electrophoresis Protocols; Tyther, R., Sheehan, D., Eds.; Humana Press: Totowa, NJ, USA, 2009. [CrossRef]

192. Tran, T.; Lafarge, C.; Pradelles, R.; Perrier-Cornet, J.; Cayot, N.; Loupiac, C. Effect of High Hydrostatic Pressure on the Structure of the Soluble Protein Fraction in Porphyridium cruentum Extracts. Innov. Food Sci. Emerg. Technol. 2019, 58, 102226. [CrossRef]

193. Wang, S.; Hu, Q.; Sommerfeld, M.; Chen, F. An optimized protocol for isolation of soluble proteins from microalgae for two-dimensional gel electrophoresis analysis. J. Appl. Phycol. 2003, 15, 485-496. [CrossRef]

194. Dai, L.; Reichert, C.L.; Hinrichs, J.; Weiss, J. Acid Hydrolysis Behavior of Insoluble Protein-Rich Fraction Extracted from Chlorella protothecoides. Colloids Surf. A 2019, 569, 129-136. [CrossRef]

195. Lipkens, B.; Mitchell, E.; Carmichael, J.; Mealey, D.; Dionne, J. Ultrasound and Acoustophoresis for Collection and Processing of Oleaginous Microorganisms. U.S. Patent 9556411B2, 31 January 2017.

196. Saxena, A.; Tripathi, B.; Kumar, M.; Shahi, V.K. Membrane-based techniques for the separation and purification of proteins: An overview. Adv. Colloid Interface Sci. 2009, 145, 1-22. [CrossRef] [PubMed] 
197. Chaiklahan, R.; Chirasuwan, N.; Loha, V.; Tia, S.; Bunnag, B. Separation and Purification of Phycocyanin from Spirulina sp. Using a Membrane Process. Bioresour. Technol. 2011, 102, 7159-7164. [CrossRef] [PubMed]

198. Gómez-Loredo, A.; Gonzále-Valdez, J.; Rito-Palomares, M. Insights on the Downstream of Fucoxanthin, a microalgal carotenoid, from an aqueous two-phase system stream exploiting ultrafiltration. J. Appl. Phycol. 2015, 27, 1517-1523. [CrossRef]

199. Barkia, I.; Saari, N.; Manning, S.R. Microalgae for High-Value Products towards Human Health and Nutrition. Mar. Drugs 2019, 17, 304. [CrossRef]

200. Kim, D.; Hwang, T.; Oh, Y.; Han, J. Harvesting Chlorella sp. KR-1 Using Cross-Flow Electro-Filtration. Algal Res. 2014, 6, 170-174. [CrossRef]

201. Furuki, T.; Maeda, S.; Imajo, S.; Hiroi, T.; Amaya, T.; Hirokawa, T.; Ito, K.; Nozawa, H. Rapid and Selective Extraction of Phycocyanin from Spirulina platensis with Ultrasonic Cell Disruption. J. Appl. Phycol. 2003, 15, 319-324. [CrossRef]

202. Lien, T.; Schreiner, Ø.; Steine, M. Purification of a Derepressible Arylsulfatase from Chlamydomonas reinhardti. Properties of the Enzyme in Intact Cells and in Purified State. Biochim. Biophys. Acta 1975, 384, 168-179. [CrossRef]

203. Mathiazakan, P.; Shing, S.Y.; Ying, S.S.; Kek, H.K.; Tang, M.S.Y.; Show, P.L.; Ooi, C.; Ling, T.C. Pilot-scale Aqueous Two-phase Floatation for Direct Recovery of Lipase Derived from Burkholderia cepacia Strain ST8. Sep. Purif. Technol. 2016, 171, 206-213. [CrossRef]

204. Leong, H.Y.; Chang, C.; Lim, J.W.; Show, P.L.; Lin, D.; Chang, J. Liquid Biphasic Systems for Oil-rich Algae Bioproducts Processing. Sustainability 2019, 11, 4682. [CrossRef]

205. Chew, K.W.; Chia, S.R.; Krishnamoorthy, R.; Tao, Y.; Chu, D.; Show, P.L. Liquid biphasic flotation for the purification of C-phycocyanin from Spirulina platensis microalga. Bioresour. Technol. 2019, 288, 121219. [CrossRef]

206. Safaei, M.; Maleki, H.; Soleimanpour, H.; Norouzy, A.; Zahiri, H.S.; Vali, H.; Noghabi, K.A. Development of a Novel Method for the Purification of C-Phycocyanin Pigment from a Local Cyanobacterial Strain Limnothrix sp. NS01 and Evaluation of Its Anticancer Properties. Sci. Rep. 2019, 9, 9474. [CrossRef] [PubMed]

207. Phong, W.N.; Show, P.L.; Teh, W.H.; Teh, T.X.; Lim, H.M.Y.; Nazri, N.S.B.; Tan, J.; Ling, T.C. Proteins Recovey from Wet Microalgae Using Liquid Biphasic Flotation (LBF). Bioresour. Technol. 2017, 244, 1329-1336. [CrossRef] [PubMed]

208. Khoo, K.S.; Chew, K.; Ooi, C.W.; Ong, H.C.; Ling, T.C.; Show, P.L. Extraction of Natural Astaxanthin from Haematococcus pluvialis Using Liquid Biphasic Flotation System. Bioresour. Technol. 2019, 290, 121794. [CrossRef]

209. Sankaran, R.; Show, P.L.; Cheng, Y.; Tao, Y.; Ao, X.; Nguyen, T.D.P.; Quyen, D.V. Integration Process for Protein Extraction from Microalgae Using Liquid Biphasic Eletric Flotation (LBEF) System. Mol. Biotechnol. 2018, 60, 749-761. [CrossRef] [PubMed]

210. Koyande, A.K.; Chew, K.W.; Lim, C.; Lee, S.Y.; Lam, M.K.; Show, P. Optimization of Protein Extraction from Chlorella vulgaris Via Nobel Sugaring-out Assisted Liquid Biphasic Electric Flotation System. Eng. Life Sci. 2019, 1-10. [CrossRef]

211. Pei, Y.C.; Li, Z.Y.; Liu, L.; Wang, J.J.; Wang, H.Y. Selective Separation of Protein and Saccharides by Ionic Liquids Aqueous Two-phase Systems. Sci. China Chem. 2010, 53, 1554-1560. [CrossRef]

212. Álvarez, M.S.; Longo, M.A.; Deive, F.J.; Rodríguez, A. Non-ionic surfactants and ionic liquids are a suitable combination for aqueous two-phase systems. Fluid Phase Equilibr. 2019, 502, 112302. [CrossRef]

213. Rachana, C.R.; Lyju, J.V. Three Phase Partitioning-A Novel Protein Purification Method. Int. J. Chem. Tech. Res. 2014, 6, $3467-3472$.

214. Dennison, C.; Lovrien, R. Three Phase Partitioning: Concentration and Purification of Proteins. Protein Expr. Purif 1997, 11, 149-161. [CrossRef]

215. Duong-Ly, K.C.; Gabelli, S.B. Salting Out of Proteins Using Ammonium Sulfate Precipitation. Methods Enzymol. 2014, 541, 85-94. [CrossRef]

216. Silva, L.A.; Kuhn, K.R.; Moraes, C.C.; Burket, A.V.; Kalil, S.J. Experimental Design as a Tool for Optimization of C-Phycocyanin Purification by Precipitation from Spirulina platensis. J. Braz. Chem. Soc. 2009, 20, 5-12. [CrossRef]

217. Herrera, A.; Boussiba, S.; Napoleone, V.; Hohlberg, A. Recovery of C-Phycocyanin from the Cyanobacterium Spirulina maxima. J. Appl. Phycol. 1989, 1, 325-331. [CrossRef]

218. Básaca-Loya, G.A.; Valdez, M.A.; Enríquez-Guevara, E.A.; Gutiérrez-Millán, L.E.; Burboa, M.G. Extraction and purification of B-Phycoerythrin from the red microalga Rhodosorus Marinus. Cienc Mar. 2009, 35, 359-368. [CrossRef]

219. Thengodkar, R.R.M.; Sivakami, S. Degradation of Chlorpyrifos by an Alkaline Phosphatase from the Cyanobacterium Spirulina platensis. Biodegradation 2010, 21, 637-644. [CrossRef] [PubMed]

220. Julianti, E.; Singgih, M.; Mulyani, L.N. Optimization of extraction method and characterization of phycocyanin pigment from Spirulina platensis. J. Math Fund. Sci. 2019, 51, 168-176. [CrossRef]

221. Muensean, K.; Kim, S.M. Purification and Characterization of $\beta$-Glucosidase Produced by Trichoderma Citrinoviride Cultivated on Microalga Chlorella vulgaris. Appl. Biochem. Microbiol. 2015, 51, 102-107. [CrossRef]

222. Chen, C.; Kao, P.; Tan, C.H.; Show, P.L.; Cheah, W.Y.; Lee, W.; Ling, T.C.; Chang, J. Using an Innovative PH-Stat CO 2 Feeding Strategy to Enhance Cell Growth and C-Phycocyanin Production from Spirulina platensis. Biochem. Eng. J. 2016, 112, 78-85. [CrossRef]

223. Robards, K.; Haddad, P.R.; Jackson, P.E. Supercritical Fluid Chromatography. In Principles and Practice of Modern Chromatography Methods; Robards, K., Haddad, P.R., Jackson, P.E., Eds.; Elsevier Academic Press: San Diego, CA, USA, 2004; pp. 381-405. [CrossRef]

224. Yuan, H.; Olesik, S.V. Supercritical fluid chromatography. In Encyclopedia of Analytical Chemistry; John Wiley \& Sons, Ltd.: New York, NY, USA, 2006. [CrossRef] 
225. Acikara, Ö.B. Ion-exchange chromatography and its applications. In Column Chromatography; Martin, D.F., Martin, B.B., Eds.; IntechOpen: Rijeka, Croatia, 2013. [CrossRef]

226. Cheng, S.; Huang, M.; Shiea, J. Thin layer chromatography/mass spectrometry. J. Chromatogr. A 2011, 1218, 2700-2711. [CrossRef]

227. Dong, M.W. Modern HPLC for Practicing Scientists; John Wiley \& Sons: New York, NY, USA, 2006. [CrossRef]

228. Niu, Z.; Pang, R.T.K.; Liu, W.; Li, W.; Cheng, R.; Yeung, W.S.B. Polymer-based precipitation preserves biological activities of extracellular vesicles from an endometrical cell line. PLOS ONE 2017, 12, e0186534. [CrossRef] 